\title{
Bathymetric properties of the Baltic Sea
}

\author{
Martin Jakobsson $^{1}$, Christian Stranne ${ }^{1}$, Matt O’Regan $^{1}$, Sarah L. Greenwood ${ }^{1}$, Bo Gustafsson ${ }^{2}$, \\ Christoph Humborg ${ }^{2}$, and Elizabeth Weidner ${ }^{1,3}$ \\ ${ }^{1}$ Department of Geological Sciences, Stockholm University, Stockholm, 10691, Sweden \\ ${ }^{2}$ The Baltic Sea Centre, Stockholm University, Stockholm, 10691, Sweden \\ ${ }^{3}$ Department of Earth Science, University of New Hampshire, 56 College Road, Durham, NH, USA
}

Correspondence: Martin Jakobsson (martin.jakobsson@geo.su.se)

Received: 3 March 2019 - Discussion started: 14 March 2019

Revised: 16 June 2019 - Accepted: 18 June 2019 - Published: 16 July 2019

\begin{abstract}
Baltic Sea bathymetric properties are analysed here using the newly released digital bathymetric model (DBM) by the European Marine Observation and Data Network (EMODnet). The analyses include hypsometry, volume, descriptive depth statistics, and kilometre-scale seafloor ruggedness, i.e. terrain heterogeneity, for the Baltic Sea as a whole as well as for 17 sub-basins defined by the Baltic Marine Environment Protection Commission (HELCOM). We compare the new EMODnet DBM with IOWTOPO the previously most widely used DBM of the Baltic Se aproduced by the Leibniz-Institut für Ostseeforschung Warnemünde (IOW), which has served as the primary gridded bathymetric resource in physical and environmental studies for nearly two decades. The area of deep water exchange between the Bothnian Sea and the Northern Baltic Proper across the Åland Sea is specifically analysed in terms of depths and locations of critical bathymetric sills. The EMODnet DBM provides a bathymetric sill depth of $88 \mathrm{~m}$ at the northern side of the Aland Sea and $60 \mathrm{~m}$ at the southern side, differing from previously identified sill depths of 100 and $70 \mathrm{~m}$, respectively. High-resolution multibeam bathymetry acquired from this deep water exchange path, where vigorous bottom currents interacted with the seafloor, allows us to assess what presently available DBMs are missing in terms of physical characterization of the seafloor. Our study highlights the need for continued work towards complete high-resolution mapping of the Baltic Sea seafloor.
\end{abstract}

\section{Introduction}

The Baltic Sea's bathymetric properties - including its hypsometry, bottom ruggedness and depths of critical sills, influencing water, nutrient and carbon exchange between the major basins (e.g. Bendtsen et al., 2009; Gogina and Zettler, 2010; Omstedt et al., 2014; Stigebrandt, 2001; Rolff and Elfwing, 2015), internal mixing in deep waters (Lappe and Umlauf, 2016; Nohr and Gustafsson, 2009), and bottom habitats (Kaskela and Kotilainen, 2017) - are necessary input parameters to many physical and environmental studies. Bathymetry is needed in almost all fields of marine science, preferably compiled into a digital bathymetric model (DBM) suitable for analyses and/or as a framework in numerical models (Hell et al., 2012). A DBM is a digital terrain model (DTM; see Li, 2004) where the terrain specifically represents the seafloor, commonly formatted as a regular grid with depths assigned to the grid cells.

The spatial boundaries of the Baltic Sea are formally defined in the published third edition of the International Hydrographic Organization (IHO) document S-23 "Limits of oceans and seas" (International Hydrographic Organization, 1953). This definition does not include the Kattegat, the Sound, or the belt seas (Fig. 1). The third edition of S-23 includes three subdivisions of the Baltic Sea: Gulf of Bothnia, Gulf of Finland, and Gulf of Riga. Although not stated in S-23, the water body outside of these three subdivided areas has commonly been referred to as the Baltic Proper. The Baltic Marine Environment Protection Commission (HELCOM), a.k.a. the Helsinki Commission, is an intergovernmental organization formed in 1974 to coordinate and govern actions aimed to protect the environment of the Baltic Sea. 


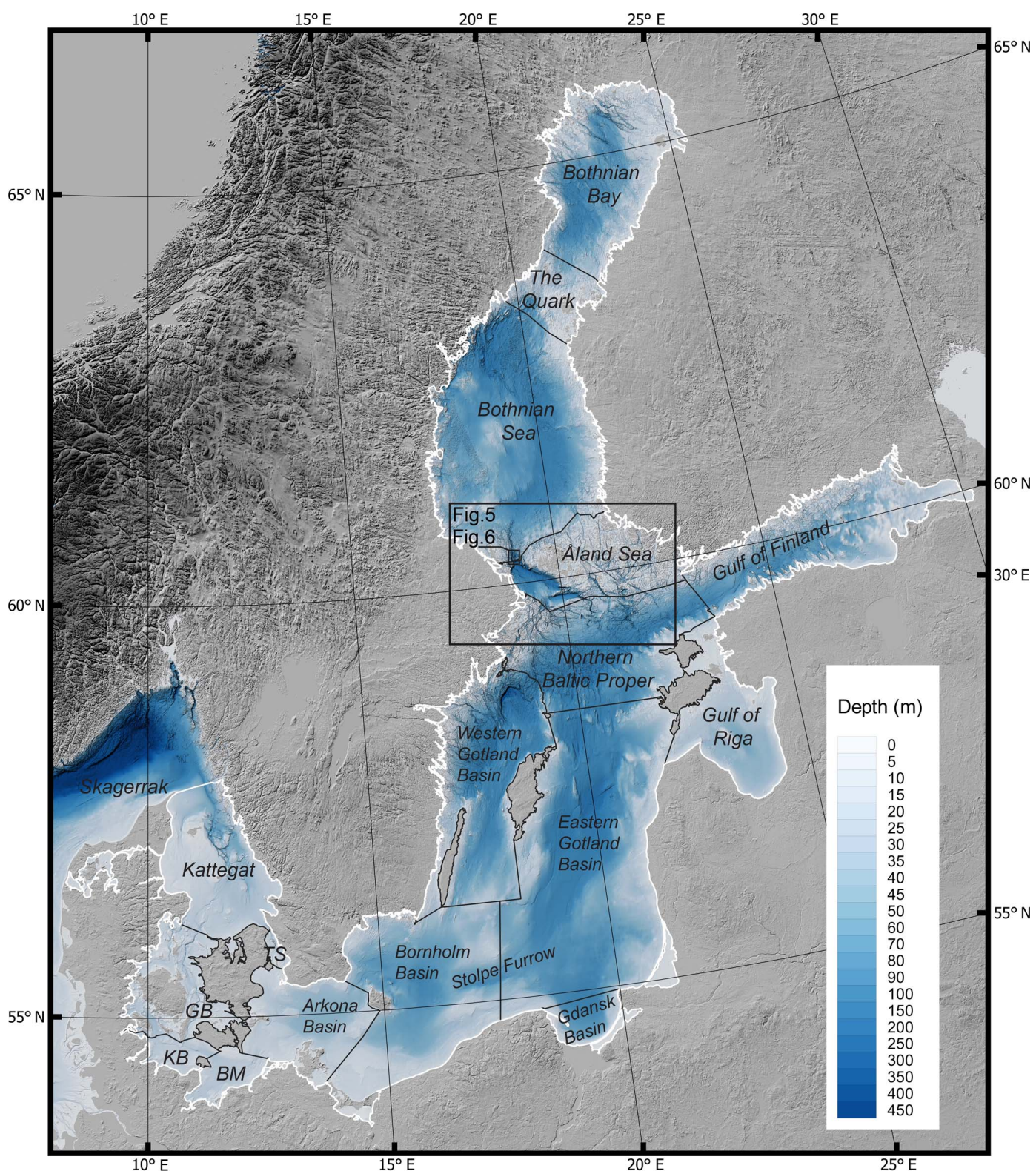

Figure 1. Bathymetric map of the Baltic Sea based on the EMODnet 2018 DBM. The HELCOM-adopted outer limit of the Baltic Sea is shown with a white line and borders between 17 HELCOM-defined sub-basins are shown with black lines. BM is Bay of Mecklenburg; GB is Great Belt; KB is Kiel Basin; TS is the Sound.

HELCOM has implemented a definition of the "Baltic Sea area" that includes the Kattegat, the Sound and the belt seas. Furthermore, based on bathymetry and hydrology, HELCOM has defined 17 sub-basins aimed to serve as areas where measured parameters describing the marine environment are to be assessed and compared regularly (HELCOM, 2018) (Fig. 1).

Here we analyse the Baltic Sea bathymetry using the newly released DBM by the European Marine Observation and Data Network (EMODnet) (EMODnet Bathymetry Consortium, 2018). This DBM has a resolution of $1 / 16 \operatorname{arcmin} \times$
$1 / 16 \operatorname{arcmin}(\sim 115 \mathrm{~m}$ latitudinal $\times 47-68 \mathrm{~m}$ longitudinal $)$, which is substantially higher than previously released by the EMODnet Bathymetry Consortium or other efforts available to the scientific community (Seifert and Kayser, 1995; Seifert et al., 2001; Hell and Öiås, 2014). We adopt the HELCOM definition of the Baltic Sea area and derive geomorphometrical parameters, including hypsometry and descriptive depth statistics, for each of the 17 defined sub-basins as well as for the Baltic Sea as a whole. We additionally explore kilometrescale seafloor ruggedness, i.e. terrain heterogeneity, across the entire Baltic. 
Up until late 2013 when the Baltic Sea Bathymetry Database (BSBD) was released (Hell and Öiås, 2014), the most widely used DBM of the Baltic Sea was compiled at the Leibniz Institute for Baltic Sea Research (IOW) and referred to as IOWTOPO, compiled at the Leibniz Institute for Baltic Sea Research, Warnemünde (Seifert et al., 2001; Seifert and Kayser, 1995). IOWTOPO provides a grid-cell size of $2 \operatorname{arcmin} \times 1$ arcmin (longitude $\times$ latitude) over the entire Baltic Sea (IOWTOPO2) and double the resolution in the southern region up to $56^{\circ} 30^{\prime} \mathrm{N}$ (IOWTOPO1). Since IOWTOPO has served as a base for many environmental studies, provided a bathymetric framework in numerical models (Dargahi et al., 2017; Meier et al., 2003; Tuomi et al., 2018; Lessin et al., 2014) and represented the Baltic Sea in other DBMs covering larger areas of the world oceans (Jakobsson et al., 2008), we include a comparison between IOWTOPO and the newly released EMODnet. The depths and locations of critical bathymetric sills governing deep water exchange between the Bothnian Sea and the Northern Baltic Proper (Fig. 1) are identified and analysed in both DBMs. Furthermore, in the path of this deep water exchange, geophysical mapping data are presented from Stockholm University's Research Vessel (R/V) Electra, permitting us to assess how metre-scale resolution portrayal of the seafloor bathymetry can improve identification and analyses of seafloor processes. Interaction of past and present currents is clearly visible in the high-resolution mapping data as well as the occurrence of substantial mass wasting. These observations highlight what we are missing in presently available DBMs and the need for continued work towards complete high-resolution mapping of the Baltic Sea seafloor.

\section{Material and methods}

\subsection{Digital bathymetric models and their sources of error}

The resolution of a DBM refers to the size of its grid cells. However, since the depth or height assigned to a grid cell may have resulted from interpolation of source data relatively far from the cell itself, it may be a misleading measure, in particular in the marine realm where the vast part of the world ocean floor remains unmapped (Mayer et al., 2018). Therefore, information about the underlying source data is required and should be made available along with the release of the DBM. In this work we analyse the EMODnet DBM released in 2018 and compare it with the latest update of IOWTOPO1 and IOWTOPO2 from 2008. The EMODnet bathymetric portal provides source references through an online interactive map tool (http://portal.emodnet-bathymetry.eu, last access: 2 July 2019). This tool makes it possible to investigate the underlying bathymetric sources in any specific area. Furthermore, EMODnet provides standard deviations of the grid-cell depths where it was possible to acquire this information from the source data. In the Baltic Sea, the standard deviation is mostly assigned a value of $0 \mathrm{~m}$, which is far from realistic and simply reflecting a lack of information about the contributed data sources and that depths assigned to grid cells in some areas are interpolated from sparse depth data from charts. It should be noted that this problem is rather restricted to the Baltic Sea because of legal restrictions regarding highresolution bathymetric information, specifically an issue in Sweden and Finland. Error estimations of DBMs based on heterogenic depth data coverages are far from trivial but can be made if access to the source data and metadata describing data acquisition and associated errors are available. However, even with this information, it is not straight forward to propagate source data errors to the final depths of the grid cells, which may result from interpolation in the case of sparse source data or subsampling in the case of high data density. Jakobsson et al. (2002) used Monte Carlo simulation to estimate the random error component of an interpolated bathymetric grid by assigning the uncertainties to each contributed source data from information about the navigation and echo sounding systems. The lack of information about the uncertainties associated with the EMODnet grid-cell depths implies that we have to report all results without an estimated uncertainty. However, the differences we reveal when comparing the DBMs in focus are far beyond any possible associated errors in their underlying data sources. They are of a different magnitude and an effect from largely different underlying source data coverage, which will be discussed.

IOWTOPO1 and IOWTOPO2 are based on soundings and depth contours, digitized from available bathymetric charts of different scales, and echo soundings along ship tracks in the deepest parts of the Arkona Basin, the Bornholm Basin, the Stolpe Furrow, and the Eastern Gotland Basin (Fig. 1) (Seifert et al., 2001; Seifert and Kayser, 1995). IOWTOPO1 and IOWTOPO2 include a parameter indicating either the number of original depth values used to derive the mean, minimum, and maximum depths in a cell or, if the cell does not contain any original depth information, the number of neighbouring cells that are used to interpolate a depth. In our comparison, we will mainly make use of the derived mean depths in the cells of both DBMs, although when discussing the deepest location in a given area and bathymetric sills the deepest depths of grid cells will be used in addition when available.

A more detailed DBM of the entire Baltic Sea bathymetry than IOWTOPO is provided by BSBD (Hell and Öiås, 2014). This DBM has a grid-cell size of $500 \mathrm{~m} \times 500 \mathrm{~m}$ on a Lambert azimuthal equal area projection. The compilation work was initiated within a working group of the Baltic Sea Hydrographic Commission (BSHC), consisting of governmental agencies around the Baltic with hydrographic charting responsibilities. BSBD is based on a significant amount of additional bathymetric source data compared to IOWTOPO. Hell and Öiås (2014) estimated that between about $30 \%$ and $50 \%$ of the Baltic Sea had been mapped to modern standards, 
primarily using multibeam echo sounders, at the time of the compilation. The spatial coverage of source data is, however, highly heterogeneous and gridding to a much higher resolution than $500 \mathrm{~m} \times 500 \mathrm{~m}$ would have been possible in many areas of the Baltic Sea (Hell and Öiås, 2014). An online map tool, including a link to downloadable grid data, also exists for BSBD, which allows the user to view the source data density but not the precise origin of the sources (http://data.bshc.pro, last access: 2 July 2019). The newly released EMODnet DBM is to some extent based on the same bathymetric source data as the BSBD, although new data have been added, specifically in the waters of Poland and Latvia. Furthermore, the input data in Swedish waters were filtered to $300 \mathrm{~m} \times 300 \mathrm{~m}$ to meet the nation's legal restrictions; however, this provides a more detailed view than the $500 \mathrm{~m} \times 500 \mathrm{~m}$ BSBD. All bathymetric source data were compiled on a grid with spherical coordinates at the higher resolution of $1 / 16 \operatorname{arcmin} \times 1 / 16$ arcmin $(\sim 115 \mathrm{~m}$ latitudinal $\times 47-68 \mathrm{~m}$ longitudinal). The Swedish Maritime Administration that led the BSBD compilation work was also responsible for providing the bathymetry in the Swedish waters within EMODnet.

\subsection{Geodetic coordinate reference system and limits of the Baltic Sea}

Before geomorphometric parameters were computed for the EMODnet and IOWTOPO DBMs, the two datasets were projected to Lambert azimuthal equal area projection with the parameters specified in the European Terrestrial Reference System (ETRS) 1989 (ETRS89-LAEA). This geodetic coordinate reference system is recommended by the EU INSPIRE Directive for statistical analyses of data spanning large parts of Europe when true area representations are required (INSPIRE Thematic Working Group Coordinate Reference Systems and Geographical Grid Systems, 2010). ETRS-89 uses the reference ellipsoid GRS 1980 and the projection parameters are found in most geographic information system (GIS) software by searching for the European Petroleum Survey Group (EPSG) code 3035. During the projection process, IOWTOPO1 and IOWTOPO2 were combined and resampled to $1000 \mathrm{~m} \times 1000 \mathrm{~m}$ and EMODnet was resampled to $115 \mathrm{~m} \times 115 \mathrm{~m}$, i.e. close to the respective DBMs' original grid-cell sizes in geographic spherical coordinates. The resampling and projection of grids as well as the vector processing described below were carried out using tools available within QGIS, version 3.4.2-Madeira (QGIS Development Team, 2018).

Polygons delineating the Baltic Sea and the 17 defined sub-basins were downloaded in shape-file format from HEL$\mathrm{COM}$. These were dissolved so that only one outer boundary remained for each individual sub-basin as well as for the polygon representing the entire Baltic Sea, i.e. all islands were removed (Fig. 1). The polygons representing the Baltic Sea and all 17 sub-basins were subsequently simplified using the Douglas-Peucker algorithm so that the minimum spacing between the nodes was left to be equal to or higher than $100 \mathrm{~m}$. The simplified polygons were used in all geomorphometric calculations to constrain them to the HELCOMdefined Baltic Sea or any of its 17 sub-basins.

\subsection{Geomorphometry}

Geomorphometry is the field of quantitative analysis aimed to describe and characterize the Earth's surface terrain (Pike et al., 2008). It commonly involves analyses of DTMs using GIS software. Hypsometry is a widely used geomorphometric parameter referring to measured heights or depths relative to sea level. A hypsometric curve displays the area distribution as a function of height or depth within a given geographic region. The tool "Hypsometric curves" in QGIS was used to derive hypsometric curves for the EMODnet and combined IOWTOPO1 and IOWTOPO2 DBMs in all 17 sub-basins as well as for the entire Baltic Sea as one region. Area calculations were made in QGIS at $1 \mathrm{~m}$ depth intervals planimetrically on the ETRS89-LAEA coordinate reference system. Descriptive statistics on the mean depths provided by the DBMs were calculated using the "Zonal Statistics" tool in QGIS. It should be noted that the reported maximum depths in each sub-basin are a "mean" maximum depth from a specific grid cell since the EMODnet does not report max values for each grid cell as some data contributors only provided mean depths.

A quantitative measure of seafloor ruggedness, sometimes referred to as roughness, can be computed using several different methods (e.g. Wilson et al., 2007; Pike et al., 2008). Here we calculate terrain ruggedness index (TRI) using the algorithm available within the open-source SAGA (System for Automated Geoscientific Analyses) tools (Conrad et al., 2015). TRI provides a measure of the bathymetric/topographic variation around a central pixel (Riley et al., 1999). The sum of the absolute differences between the neighbouring cells and the centre cell is averaged. For $3 \times 3$ grid cells this follows

$\mathrm{TRI}=\frac{\sum_{i=1}^{n} \sum_{j=1}^{n}\left\|x_{i j}-x_{\text {centre }}\right\|}{n^{2}-1}$,

where $x_{i j}$ is the depth of each neighbouring cell relative to the centre cell $x_{\text {centre }}$. For a $3 \times 3$ block of grid cells the centre cell is $x_{22}$ and $n=3$. The result is scale dependent, i.e. dependent on the grid-cell resolution of the analysed DTM. For this reason, it is common to vary the size of the region over which the terrain is analysed, i.e. the "neighbourhood", depending on whether the study is concerned with local or regional variations. In Eq. (1) this is simply done by increasing the block of grid cells for which the sum of the absolute differences is compared to the central cell. Our study aims to provide a regional basin-scale perspective. A radius of 10 grid cells 
$(1000 \mathrm{~m})$, yielding a total block size of $2100 \mathrm{~m} \times 2100 \mathrm{~m}$, was decided on after trials to provide interpretable results.

\subsection{Bathymetric sills}

Locations of bathymetric sills, i.e. the deepest depth of a generally shallow zone that would otherwise hinder transfer of water and sediment between two basins, were mapped and analysed using the software Fledermaus by QPS and QGIS. The sills were first identified in the EMODnet DBM. Bathymetric profiles perpendicular to the sills were then generated and compared to profiles between the same points generated from the IOW bathymetry.

\subsection{Geophysical mapping with R/V Electra}

Expedition EL17-IGV04 with R/V Electra carried out marine geophysical mapping within a focused area in the Southern Quark between Sweden and Åland from 6 to $17 \mathrm{Au}-$ gust 2017 (Fig. 1). The complete field work included geological coring, oceanographic stations, in situ sediment temperature logging, and geophysical mapping including multibeam bathymetry, sub-bottom profiling, and midwater sonar. We briefly describe the acquisition methods of the data presented in this work, i.e. the multibeam bathymetry and midwater imagery. R/V Electra has a Kongsberg EM2040 $0.4^{\circ} \times 0.7^{\circ}, 200-400 \mathrm{kHz}$, multibeam echo sounder and a Kongsberg EK80 wideband split-beam sonar for midwater mapping, operating at two frequencies $(70$ and $200 \mathrm{kHz})$. The multibeam is operated using Kongsberg's seafloor information system (SIS), version 4.3.2 (Build 31, DBVersion 30.0) while the split-beam sonar is operated using Kongsberg's dedicated software, EK80 version 1.8.3. Both systems receive position, heading, and attitude data from a Kongsberg Seatex Seapath 330+ navigation unit with the MRU5+ motion and reference sensor. The system is dual frequency (L1/L2 band) and capable of using both GPS and GLONASS satellites. Real-time kinematic (RTK) corrections were received from SWEPOS (https://swepos.lantmateriet.se/, last access: 2 June 2019) over the internet. This resulted in a horizontal accuracy generally below $5 \mathrm{~cm}$ and and a slightly coarser vertical accuracy. Post-processing of the multibeam bathymetry was done using QIMERA software by QPS, version 1.7.2, and midwater images from the EK80 data were compiled using MATLAB routines.

\section{Results}

\subsection{Geomorphometry}

By comparing the hypsometric curves of two different DBMs of the same region, differences in specific depth intervals can readily be identified as well as systematic biases in the bathymetric source data. Smith and Sandwell (1997) showed that a bias towards gridded digitized depth contours could be seen as spikes in the hypsometric curve of ETOPO-5, the first global gridded compilation of the world ocean (National Geophysical Data Center, 1988). Biases towards 10 and $5 \mathrm{~m}$ intervals are clearly seen in the IOWTOPO hypsometric curve representing the entire Baltic Sea, specifically pronounced between 100 and $50 \mathrm{~m}$ (Fig. 2a). Here the biases are clearly an effect of depths being sampled from charts in steps of 10,5 , and $1 \mathrm{~m}$ within the depth intervals deeper than 150 , $150-50$, and 50-0 m, respectively (Seifert and Kayser, 1995). A clearly visible difference between the IOWTOPO and EMODnet bathymetries is identified at depths shallower than $\sim 15 \mathrm{~m}$ where IOWTOPO has much larger shallow areas (Fig. 2a). Apart from this difference and the spikes, the hypsometric curves of the two DBMs are rather similar, but with a more persistent deviation between 40 and $25 \mathrm{~m}$.

The analyses of the 17 sub-basins show that differences in depths shallower than $\sim 15 \mathrm{~m}$ are less apparent in Kattegat, Kiel Bay, Gdansk Basin, and Eastern Gotland Basin (Fig. 2b, e, i, j). Spikes related to biased sampling of data at 10 and $5 \mathrm{~m}$ intervals in the IOWTOPO DBM are more visible in Bornholm Basin, Eastern Gotland Basin, and Bothnian Sea (Fig. 2h, j, p). The largest differences in the hypsometry are apparent for the Gulf of Finland and the Quark (Fig. 2n and q).

The overall shallower character of the IOWTOPO DBM is apparent in the descriptive statistics. The median (mean) depths of IOWTOPO and EMODnet within the Baltic Sea limits are 39 (50) and 42 (53) m, respectively (Fig. 2, Table 1). All sub-basins have deeper median and mean depths in EMODnet, except for Kattegat and Eastern Gotland Basin (Fig. 3, Table 1). Eastern Gotland Basin has the deepest median and mean in IOWTOPO, while this is instead the case for Northern Baltic Proper in EMODnet. Across all metrics plotted in Fig. 3, the greatest deviation between the IOWTOPO and EMODnet DBMs is seen in the Western Gotland Basin, Northern Baltic Proper, Åland Sea, and the Quark. These cases cover shallow, moderate, and deep basins, indicating dataset deviation at all depths on a sub-basin scale. Alland Sea has the largest difference in median and mean depths between IOWTOPO and EMODnet, with a median (mean) of 7 (26) m compared to 19 (37) m, respectively (Fig. 3, Table 1).

The area of the Baltic Sea, calculated by summarizing all grid cells of the EMODnet DBM falling within the HELCOM-defined boundary and with values of $\leq 0 \mathrm{~m}$, is $\sim 417 \times 10^{3} \mathrm{~km}^{2}\left(417115 \mathrm{~km}^{2}\right)$ (Table 1). The area comes out $\sim 0.2 \%$ smaller when summarizing the separate areas of the sub-basins due to "loss" of grid cells because the QGIS routine only counts complete cells falling within the polygon boundaries. Furthermore, it should be noted that counting grid cells yields a combined area of all the sub-basins that is $\sim 0.1 \%$ smaller than when the HELCOM original polygons of the sub-basins are used to calculate the area of the Baltic Sea. The reason for this is likely the same, i.e. grid cells only partially within the delimiting polygons 
(a)

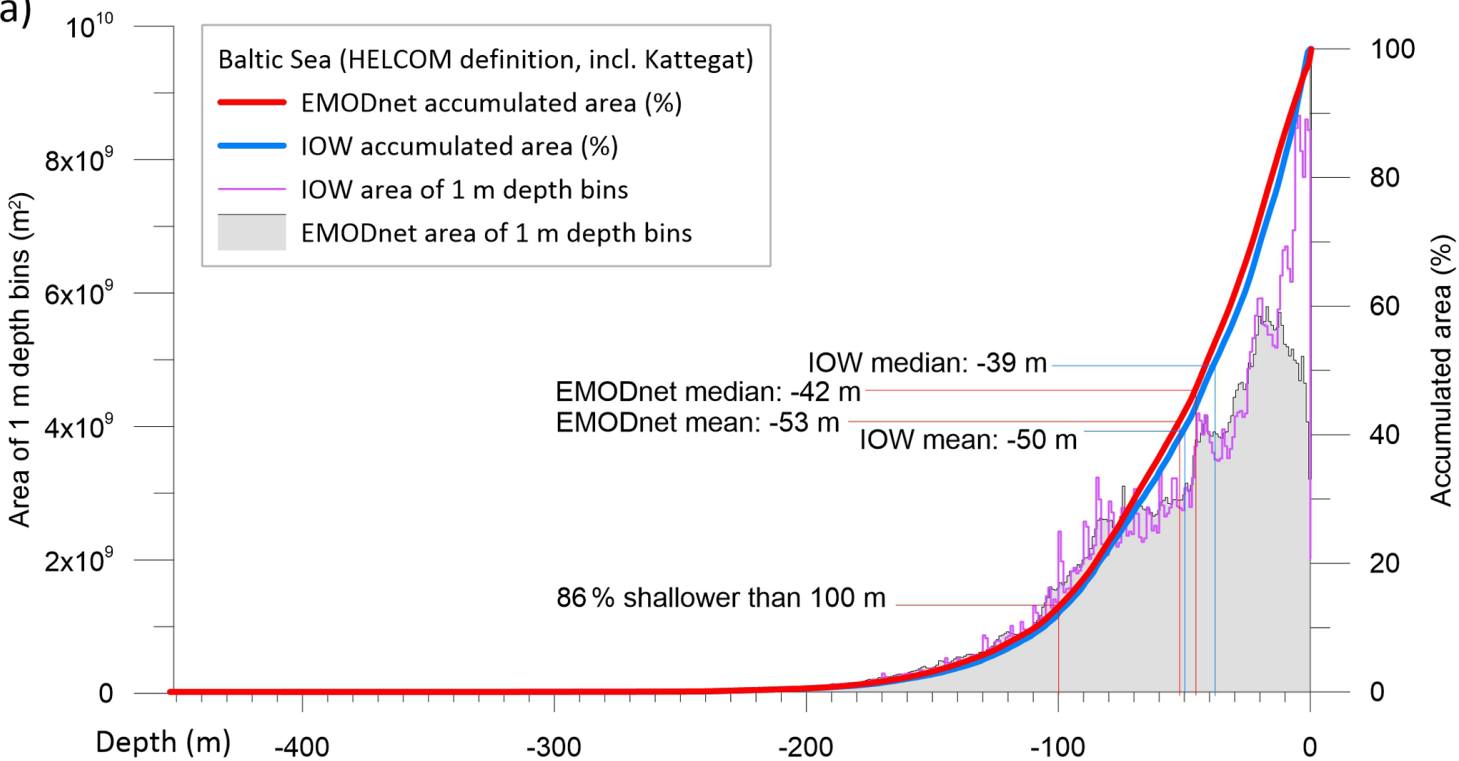

(b)

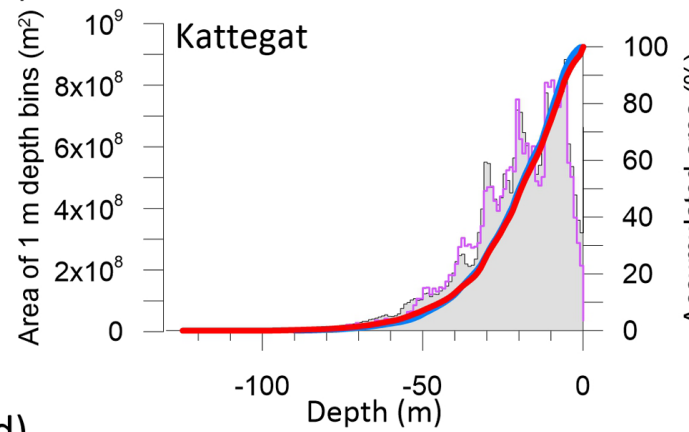

(d)

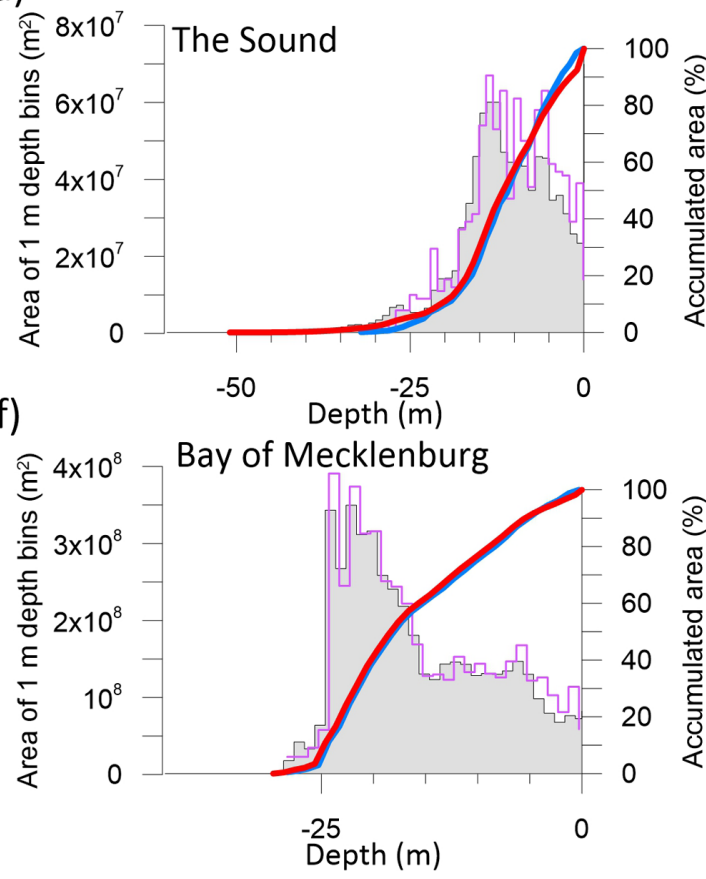

(c)

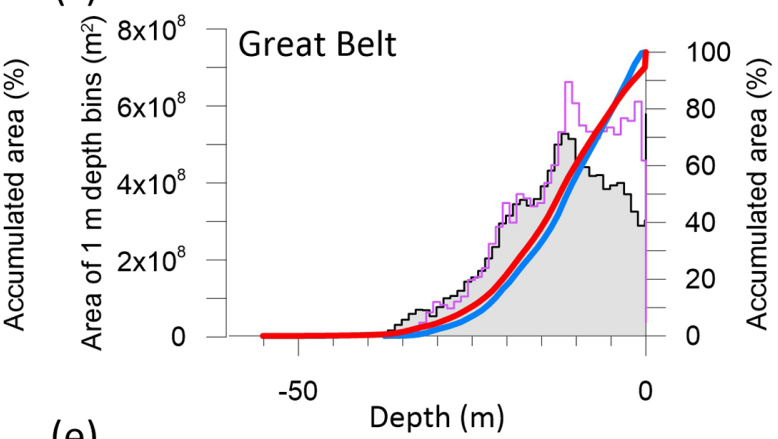

(e)
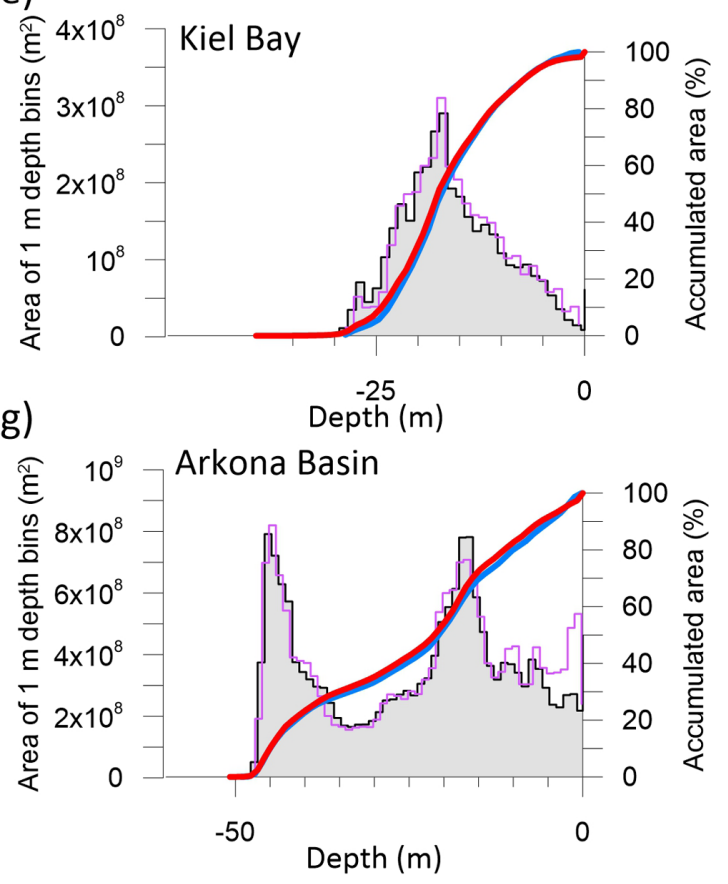

Figure 2. 
(h)

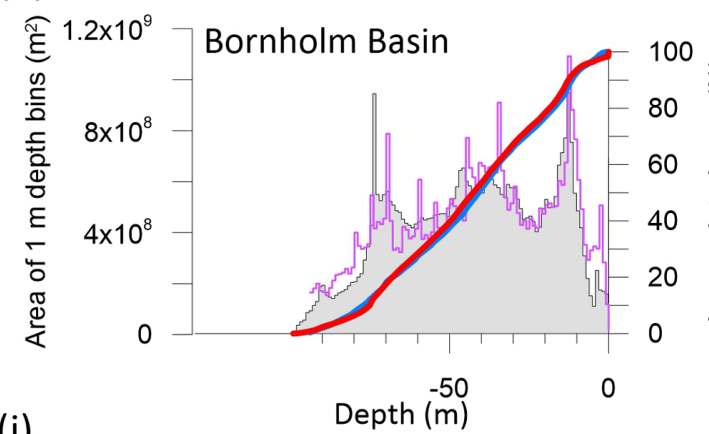

(j)

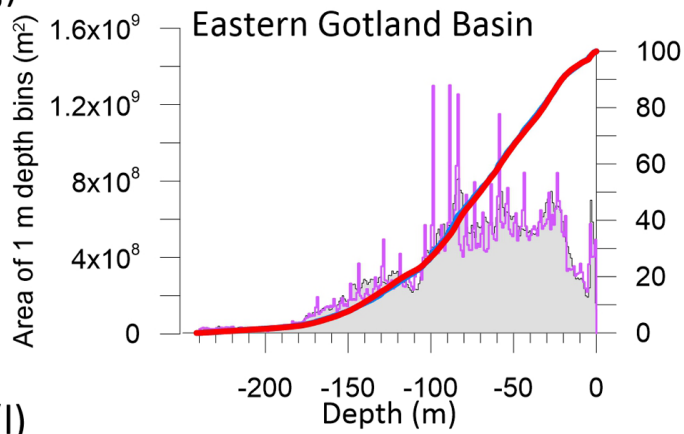

(I)

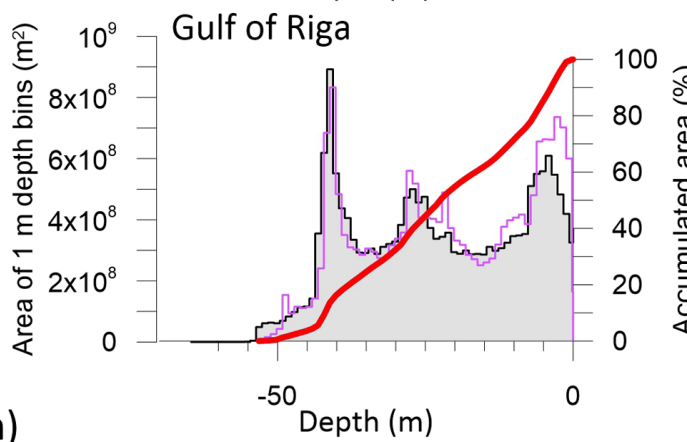

(n)

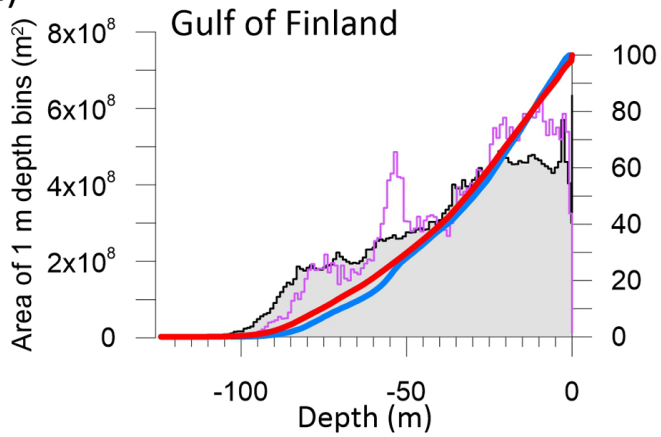

(i)

(k)
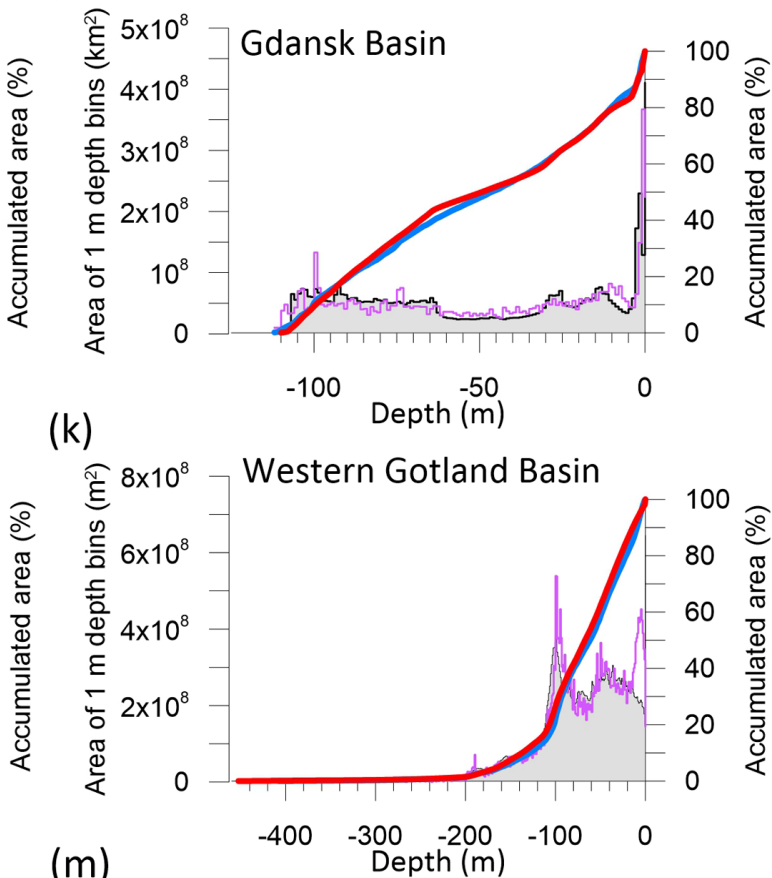

(m)

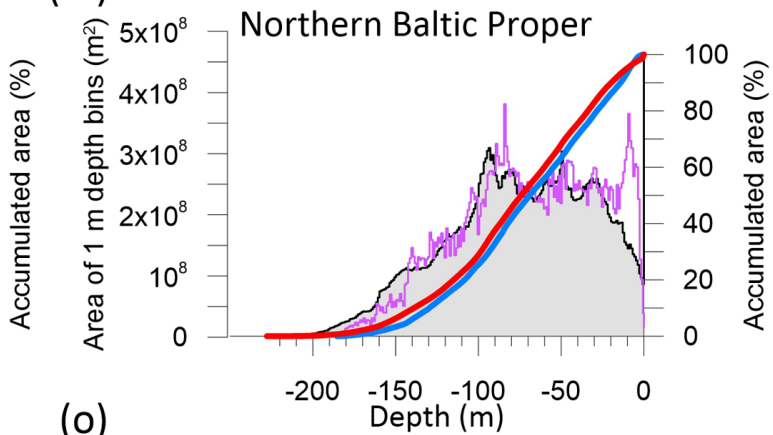

(0)

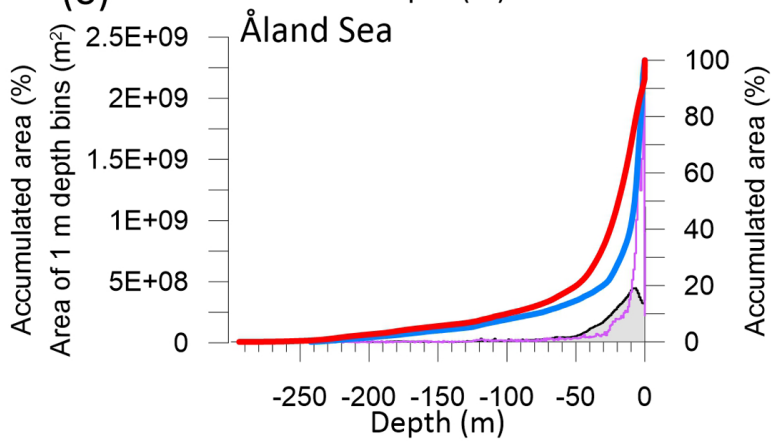

Figure 2.

are omitted. However, these differences are very small and since this study aims to analyse the DBMs, we have counted grid cells on the Lambert equal area projection for all area calculations. The coarser IOWTOPO DBM has an area of $\sim 427 \times 10^{3} \mathrm{~km}^{2}\left(427470 \mathrm{~km}^{2}\right)$, which is as much as $\sim 2.5 \%$ larger than EMODnet. This can most likely be explained by the coarser resolution and all islands that are left out. The volume of the Baltic Sea is $\sim 21.9 \times 10^{3} \mathrm{~km}^{3}\left(21971 \mathrm{~km}^{3}\right)$ using EMODnet and $\sim 21.2 \times 10^{3} \mathrm{~km}^{3}\left(21258 \mathrm{~km}^{3}\right)$ using IOWTOPO, i.e. the latter yields a $\sim 3.1 \%$ smaller volume (Table 1). This can be explained by the shallow bias in IOWTOPO seen in the hypsometry.

On a basin scale, the ruggedness of the seafloor is shown to vary spatially (Fig. 4). Particularly rugged areas are confined to the eastern part of the Kattegat, northern Western Gotland Basin from about $57^{\circ} 25^{\prime} \mathrm{N}$, northern two-thirds of 
(p)

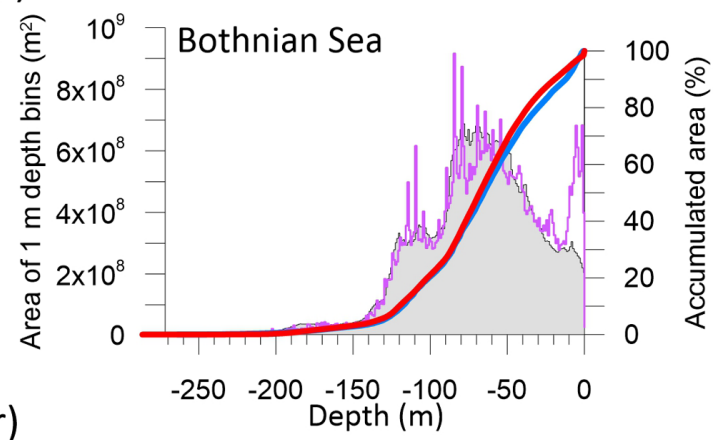

(r)

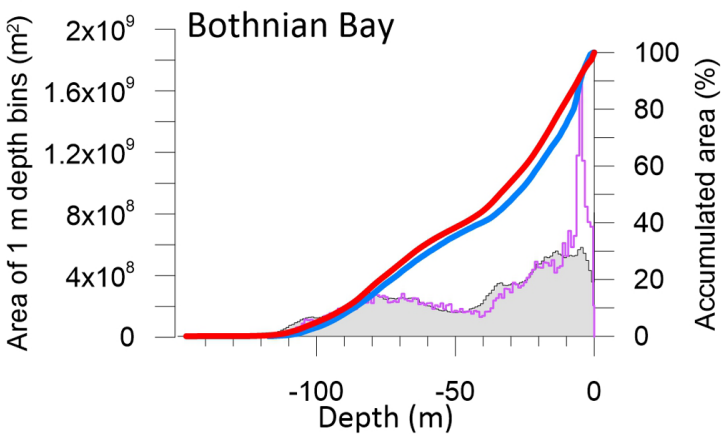

(q)

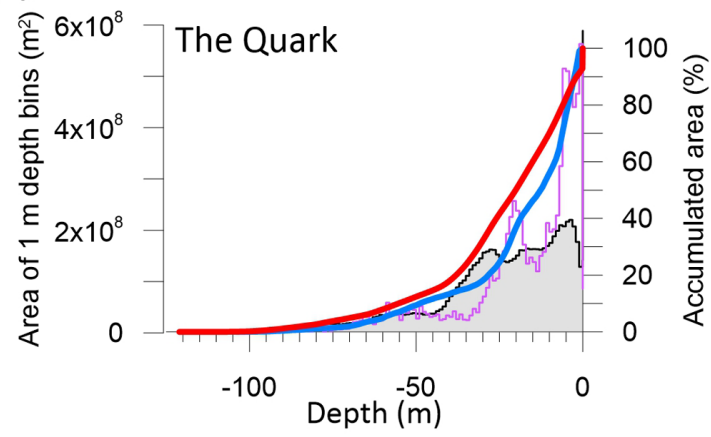

Figure 2. Hypsometry of the Baltic Sea and the 17 HELCOM-defined sub-basins. (a) Hypsometry of the entire Baltic Sea, (b-r) Hypsometry of HELCOM-defined sub-basins. Hypsometry expressed as accumulated area in percent are shown with red curves for EMODnet and blue for IOWTOPO. Hypsometry expressed as area for $1 \mathrm{~m}$ depth intervals are shown with filled grey curves for EMODnet and with purple curves for IOWTOPO.

Baltic Proper (highest TRI values near the Swedish coast), the entire Åland Sea, and northwestern sectors of Bothnian Sea and Bothnian Bay. In the Åland Sea, the rugged seafloor is clearly confined to a pattern of rather straight channels, which sometimes criss-cross each other (Fig. 4a), while in other areas the rugged seafloor shows a sinuous pattern. An example of the latter is the band of rugged seafloor stretching from the lower western corner of the Baltic Proper to about $59^{\circ} 40^{\prime} \mathrm{N}, 26^{\circ} 40^{\prime} \mathrm{E}$ in the southern Gulf of Finland (Fig. 4b). A qualitatively similar band of less pronounced sinuosity is apparent in the northern Eastern Gotland Basin. South of here, the much less rugged nature of the southern Baltic Sea is clearly apparent in the TRI map (Fig. 4). We discuss below possible sources of seafloor ruggedness but note here that inconsistencies in the bathymetric source data coverage are readily apparent in the TRI map, where roughness "borders" are unnaturally straight and clearly delineate input data with different native resolutions (Fig. 4c). This highlights the caution needed when interpreting a DBM compiled from heterogeneous source data, something that will be further addressed in the discussion.

\subsection{Bathymetric sills}

The Åland Sea separates the Bothnian Sea and the Northern Baltic Proper (Fig. 1). The seafloor bathymetry is highly complex: it is a broad zone, much of it shallow, but deep incisions cut through what otherwise could act as an effective barrier to water exchange. A deep basin is located west of the islands of Åland, with water depths exceeding $200 \mathrm{~m}$ over much of its central part (Fig. 5a). Therefore, the threshold that may influence deep water exchange between the Northern Baltic Proper and Bothnian Sea will be located north or south of this deep basin. We analyse the mean depths provided by the EMODnet 2018 DBM because in this area there are no maximum depths provided or, more precisely, those provided are the same as the mean. This is an effect of the sparse input data and the down sampling to $300 \mathrm{~m} \times 300 \mathrm{~m}$ in Swedish waters where modern multibeam bathymetry exist. The southernmost sill depth (profile $\mathrm{W}-\mathrm{W}^{\prime}$ in Fig. 5) is $\sim 60 \mathrm{~m}$ deep and located at the southern end of a nearly $40 \mathrm{~km}$ long, $\sim 1-2 \mathrm{~km}$ wide, winding channel that ends in the north in a small E-W elongated basin south of Lågskär (hereafter referred to as Lågskär Basin) with depths exceeding $150 \mathrm{~m}$ (Fig. 5a). South of the southernmost identified sill (W), the bathymetry is complex and there are a few points that also may act as sills as they are just about deeper than $60 \mathrm{~m}$. At the northern end of Lågskär Basin there are three sills slightly deeper than $60 \mathrm{~m}$, one in the east and two in the west separated by approximately $15 \mathrm{~km}$ and all situated at about the same latitude as Lågskär (profile $\mathrm{V}-\mathrm{V}^{\prime}$ in Fig. 5). North of the deep main basin of the Åland Sea, a 
(a)

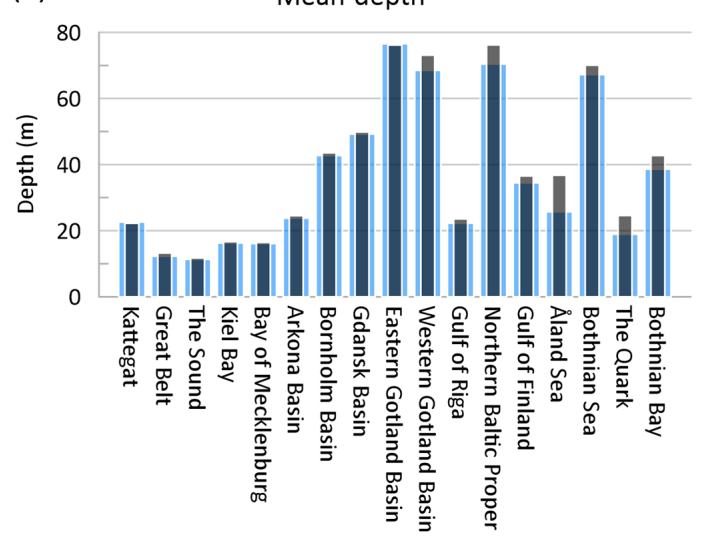

(c)

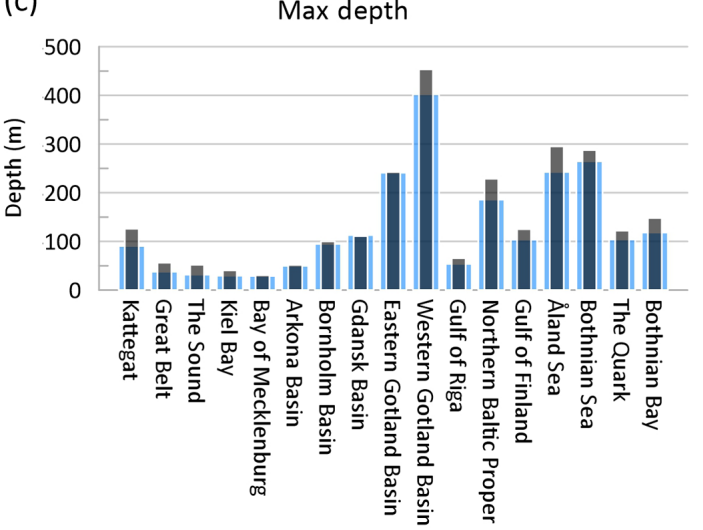

(b) Median depth

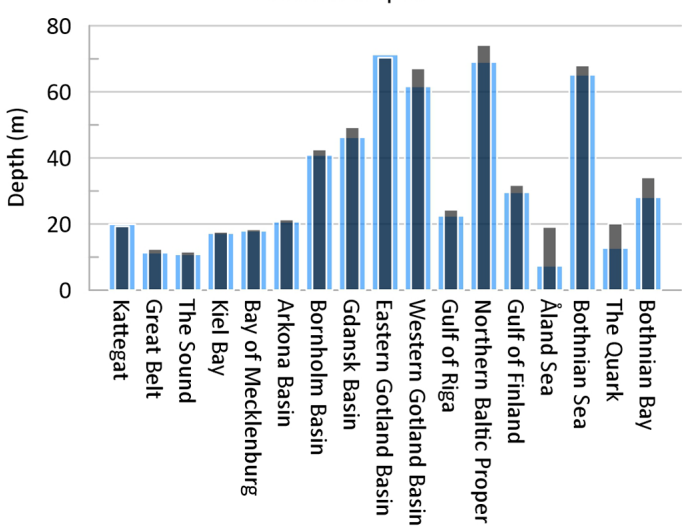

Figure 3. Comparison between mean, median, and maximum depths of the HELCOM-defined sub-basins based on the EMODnet (grey bars) and IOWTOPO (blue bars) DBMs. As for Table 1, note that the statistics are calculated from the DBMs' grid cells, which have depths representing the mean within each grid-cell area. This implies, for example, that the maximum depth in each sub-basin will be slightly deeper than shown here. (a) Mean depth; (b) median depth; (c) maximum depth.

more than $45 \mathrm{~km}$ long channel extending in an almost southnorth direction, the shallowest point just about reaching $88 \mathrm{~m}$ is shown (profile $\mathrm{U}-\mathrm{U}^{\prime}$ in Fig. 5). Our analyses of the mean depths provided by the EMODnet DBM suggest that transport from or to the Baltic Proper is limited by a $\sim 60 \mathrm{~m}$ sill south of the Åland Sea, while transport from or to the Bothnian Sea is limited by a $\sim 88 \mathrm{~m}$ threshold north of Åland (Fig. 5a).

The mean depths of the IOWTOPO DBM naturally provide a much more generalized portrayal of the seafloor morphology due to the substantially lower resolution. While the pronounced bedrock channels are not as visible in the IOWTOPO bathymetry as they are in EMODnet, the two main channels where the sills were found are (Fig. 5b). A southernmost sill occurs nearly at the same location in both datasets, although the mean depth in IOWTOPO lies at $49 \mathrm{~m}$ instead of $60 \mathrm{~m}$. Towards the main deep basin there is only one distinct deep passage of about $49 \mathrm{~m}$ instead of the three $60 \mathrm{~m}$ passages identified in EMODnet. The northern sill is located nearly at the same place as in EMODnet, although its mean depth is $57 \mathrm{~m}$ which is substantially shallower. IOWTOPO does, however, provide information on the deepest depth in the cells in this region. At the southernmost sill (profile W$\mathrm{W}^{\prime}$ ) the deepest depth is deeper than $80 \mathrm{~m}$, in fact similar to the deepest depth at the northernmost sill (profile $\mathrm{U}-\mathrm{U}^{\prime}$, Fig. 5c). The much coarser resolution of the IOWTOPO gives a shallow bias to the mean depths for the thalweg of a channel that is nearly as narrow as the grid-cell size.

\subsection{High-resolution bathymetry in the Southern Quark}

The Swedish Maritime Administration mapped large areas of the Southern Quark using multibeam data, and provided subsampled multibeam grids to the compilation of the EMODnet DBM. The IOWTOPO, on the other hand, is both of substantially lower resolution and based on gridding sparse digitized soundings. For analysis of the effects of resolution downgrading for DBM compilation, we compare the DBMs with multibeam bathymetry acquired by R/V Electra in the Southern Quark, gridded at a grid-cell size of $2.5 \mathrm{~m} \times 2.5 \mathrm{~m}$ (Figs. 6 and 7). The first-order comparison shown in Fig. 6 reveals the immense difference with IOWTOPO failing to capture the distinct $\sim 2 \mathrm{~km}$ wide western channel and the two major 
Table 1. Descriptive statistics of the EMODnet and IOWTOPO DBMs calculated using the depths of the grid cells in respective DBMs. Note that the grid cells themselves give the mean of soundings within that cell. For example, the maximum depth in the Western Gotland Basin corresponds to the Landsort Deep, commonly cited as $459 \mathrm{~m}$, yet the corresponding cell in EMODnet gives $454 \mathrm{~m}$ and in IOWTOPO is even shallower (402 m), because the coarser resolution implies that grid cells contain mean depths derived from larger areas.

\begin{tabular}{|c|c|c|c|c|c|c|c|c|c|c|c|c|}
\hline \multirow[b]{2}{*}{ HELCOM sub-basin } & \multicolumn{6}{|c|}{ EMODnet } & \multicolumn{6}{|c|}{ IOWTOPO } \\
\hline & Mean & Median & Max & SD & $\begin{array}{r}\text { Area } \\
\left(\mathrm{km}^{2}\right)\end{array}$ & $\begin{array}{r}\text { Volume } \\
\left(\mathrm{km}^{3}\right)\end{array}$ & Mean & Median & $\operatorname{Max}$ & SD & $\begin{array}{r}\text { Area } \\
\left(\mathrm{km}^{2}\right)\end{array}$ & $\begin{array}{r}\text { Volume } \\
\left(\mathrm{km}^{3}\right)\end{array}$ \\
\hline Kattegat & 22 & 19 & 126 & 16 & 23921 & 532 & 23 & 20 & 91 & 15 & 22543 & 508 \\
\hline Great Belt & 13 & 12 & 56 & 9 & 10858 & 144 & 12 & 11 & 38 & 8 & 11733 & 143 \\
\hline The Sound & 12 & 12 & 52 & 7 & 932 & 11 & 11 & 11 & 32 & 6 & 943 & 11 \\
\hline Kiel Bay & 17 & 18 & 40 & 6 & 3472 & 58 & 16 & 17 & 30 & 6 & 3475 & 57 \\
\hline Bay of Mecklenburg & 16 & 18 & 31 & 7 & 4613 & 76 & 16 & 18 & 29 & 7 & 4652 & 75 \\
\hline Arkona Basin & 25 & 21 & 52 & 14 & 17727 & 435 & 24 & 21 & 50 & 14 & 18191 & 432 \\
\hline Bornholm Basin & 44 & 43 & 100 & 24 & 42150 & 1835 & 43 & 41 & 95 & 24 & 42638 & 1822 \\
\hline Gdansk Basin & 50 & 49 & 111 & 37 & 5850 & 292 & 49 & 46 & 113 & 36 & 5833 & 287 \\
\hline Eastern Gotland Basin & 76 & 70 & 243 & 47 & 75019 & 5708 & 77 & 71 & 241 & 47 & 75132 & 5746 \\
\hline Western Gotland Basin & 73 & 67 & 454 & 51 & 34359 & 2511 & 68 & 62 & 402 & 50 & 35054 & 2398 \\
\hline Gulf of Riga & 24 & 24 & 66 & 15 & 18705 & 441 & 22 & 23 & 54 & 14 & 18990 & 423 \\
\hline Northern Baltic Proper & 76 & 74 & 229 & 44 & 32745 & 2496 & 70 & 69 & 186 & 42 & 33346 & 2348 \\
\hline Gulf of Finland & 37 & 32 & 125 & 26 & 29721 & 1087 & 34 & 30 & 104 & 23 & 30476 & 1051 \\
\hline Åland Sea & 37 & 19 & 295 & 49 & 16560 & 609 & 26 & 7 & 243 & 44 & 19494 & 501 \\
\hline Bothnian Sea & 70 & 68 & 288 & 39 & 59326 & 4158 & 67 & 65 & 265 & 41 & 59925 & 4029 \\
\hline The Quark & 25 & 20 & 122 & 21 & 8287 & 204 & 19 & 13 & 104 & 19 & 8652 & 164 \\
\hline Bothnian Bay & 43 & 34 & 148 & 32 & 32078 & 1371 & 39 & 28 & 118 & 32 & 32771 & 1265 \\
\hline Sum & & & & & 416320 & 21967 & & & & & 423848 & 21258 \\
\hline $\begin{array}{l}\text { Baltic Sea } \\
\text { (separate calculation) }\end{array}$ & 53 & 42 & 454 & 43 & 417115 & 21971 & 50 & 39 & 402 & 42 & 427470 & 21283 \\
\hline
\end{tabular}

ridges protruding east of the channel as well as the $\sim 1 \mathrm{~km}$ wide passage between them. The bathymetric profiles between $\mathrm{X}$ and $\mathrm{X}^{\prime}$ and between $\mathrm{Y}$ and $\mathrm{Y}^{\prime}$, crossing the narrow main western channel, show that the EMODnet DBM portrays the main morphology rather well compared to the highresolution R/V Electra surface, while IOWTOPO differs in depth by as much as $100 \mathrm{~m}$ in places.

A closer inspection of the R/V Electra multibeam bathymetry shows a dynamic local environment at the seafloor with, for example, visible erosional channels, mass wasting, and a sediment drift deposit (Fig. 7). There are hints of some parts of the channels and the drift deposit in the EMODnet DBM, but without knowing where to look from the higher-resolution information most features would not be possible to identify. This shows that there is still enormous value in full-resolution data for identification and interpretation of features that either drive or are a product of process interaction between seabed and overlying water column. The wreck from the $90 \mathrm{~m}$ long ship August Thyssen (sunk in 1940 after hitting a mine) at $\sim 55 \mathrm{~m}$ water depth is visible in the $2.5 \mathrm{~m} \times 2.5 \mathrm{~m}$, however, a higher-resolution rendition using the full multibeam information of $50 \mathrm{~cm} \times 50 \mathrm{~cm}$ shows that there is substantially more information in the acquired multibeam bathymetry than revealed by a $2.5 \mathrm{~m} \times 2.5 \mathrm{~m}$ grid
(Fig. 7b). There are, for obvious reasons, no signs of August Thyssen in the EMODnet DBM.

\subsection{Water column imagery}

Mid-water acoustic profiles were collected along a part of transect $\mathrm{X}-\mathrm{X}^{\prime}$ and the entire $\mathrm{Y}-\mathrm{Y}^{\prime}$ (Figs. 6 and 8). Acoustic data can be used to observe features within the water column in a similar manner as sub-bottom profilers or seismic reflection systems are able to identify geological layers within the stratigraphy below the seafloor (Jakobsson et al., 2016b). Acoustic impedance contrasts, caused by changes in water sound-velocity and density, cause reflections and scattering of the acoustic signal. Scattering from point sources as well as reflections from laterally extended acoustic impedance contrasts are clearly visible in both profiles (Fig. 8). The strongest point echoes occur in water depths between about 75 and $100 \mathrm{~m}$. There is a scattering layer below $100 \mathrm{~m}$ in transect $X-X^{\prime}$ (Fig. 8a) and a section of less coherent, but pronounced, reflections above the bathymetric peak in transect $\mathrm{Y}-\mathrm{Y}^{\prime}$ formed by the wreck (Fig. 8b). 


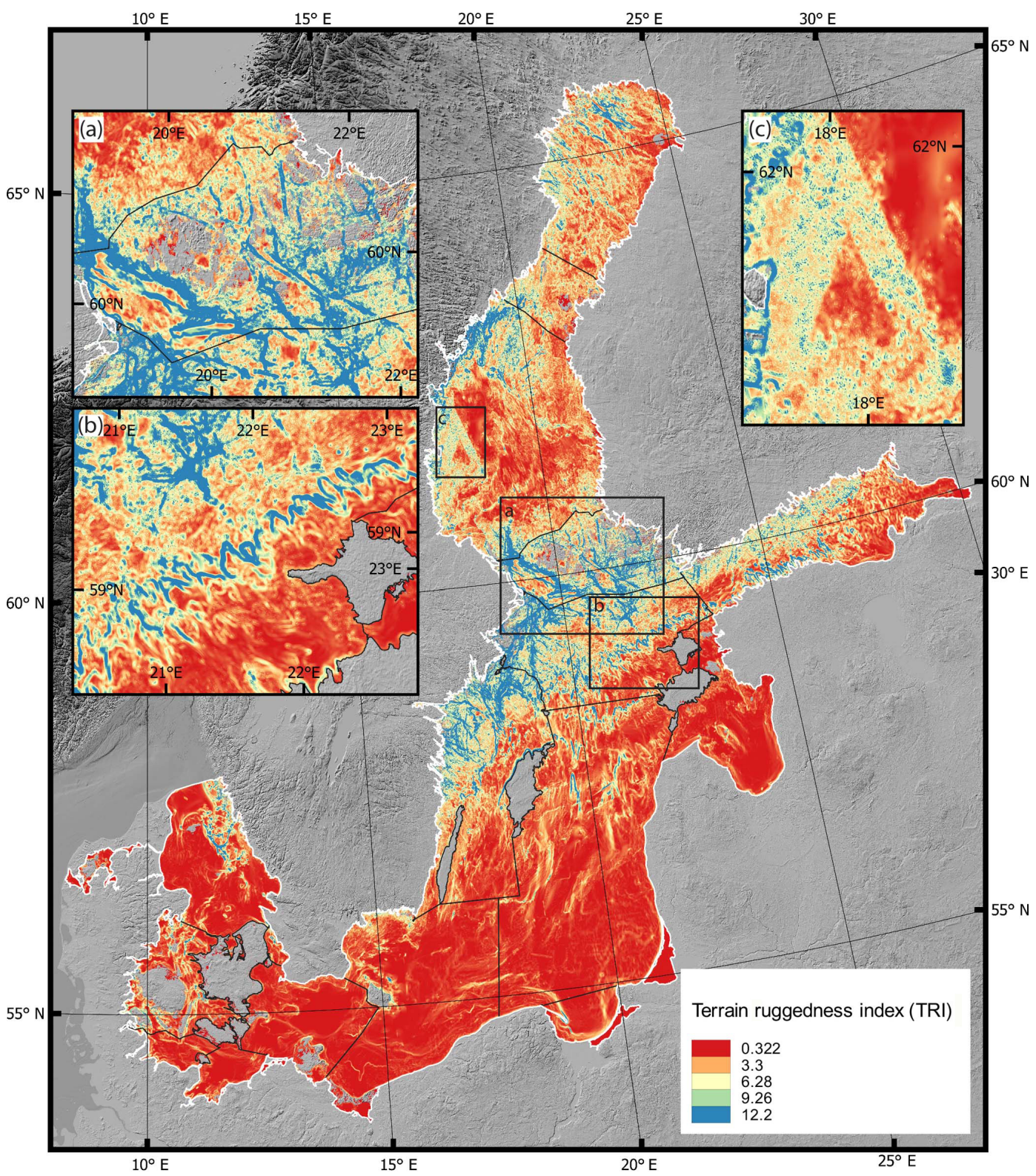

Figure 4. Calculated terrain ruggedness index (TRI) of the Baltic Sea seafloor. Areas specially discussed in the text are shown in the close-up maps $(\mathbf{a}-\mathbf{c})$.

\section{Discussion}

\subsection{Basin-scale morphology and DBM evaluation}

The Baltic Sea's bottom topography, hypsometry, and depths of critical sills between the major basins were described by Leppäranta and Myrberg (2009). Their description builds in turn on the published bathymetric characterization of the Baltic Sea by Fonselius (1995). Both these studies were based on analyses of traditional bathymetric maps with depth contours. The first compiled DBM encompassing the entire Baltic Sea was IOWTOPO2 published in 1995 (Seifert and
Kayser, 1995). While this DBM served as the primary resource for gridded Baltic bathymetry for nearly 2 decades until BSBD was released in 2014 (Hell and Öiås, 2014), it has to our knowledge not been subjected to similar bathymetric analyses as those made by Fonselius (1995) and Leppäranta and Myrberg (2009). Our study does not aim to fully replicate their seafloor analyses using the new EMODnet DBM. First, it would require that the exact same definitions of all sub-basins are applied. Second, we find it more useful to focus on comparing EMODnet with IOWTOPO and the characteristics of these two DBMs because modern uses of seafloor bathymetry rely almost exclusively on gridded 

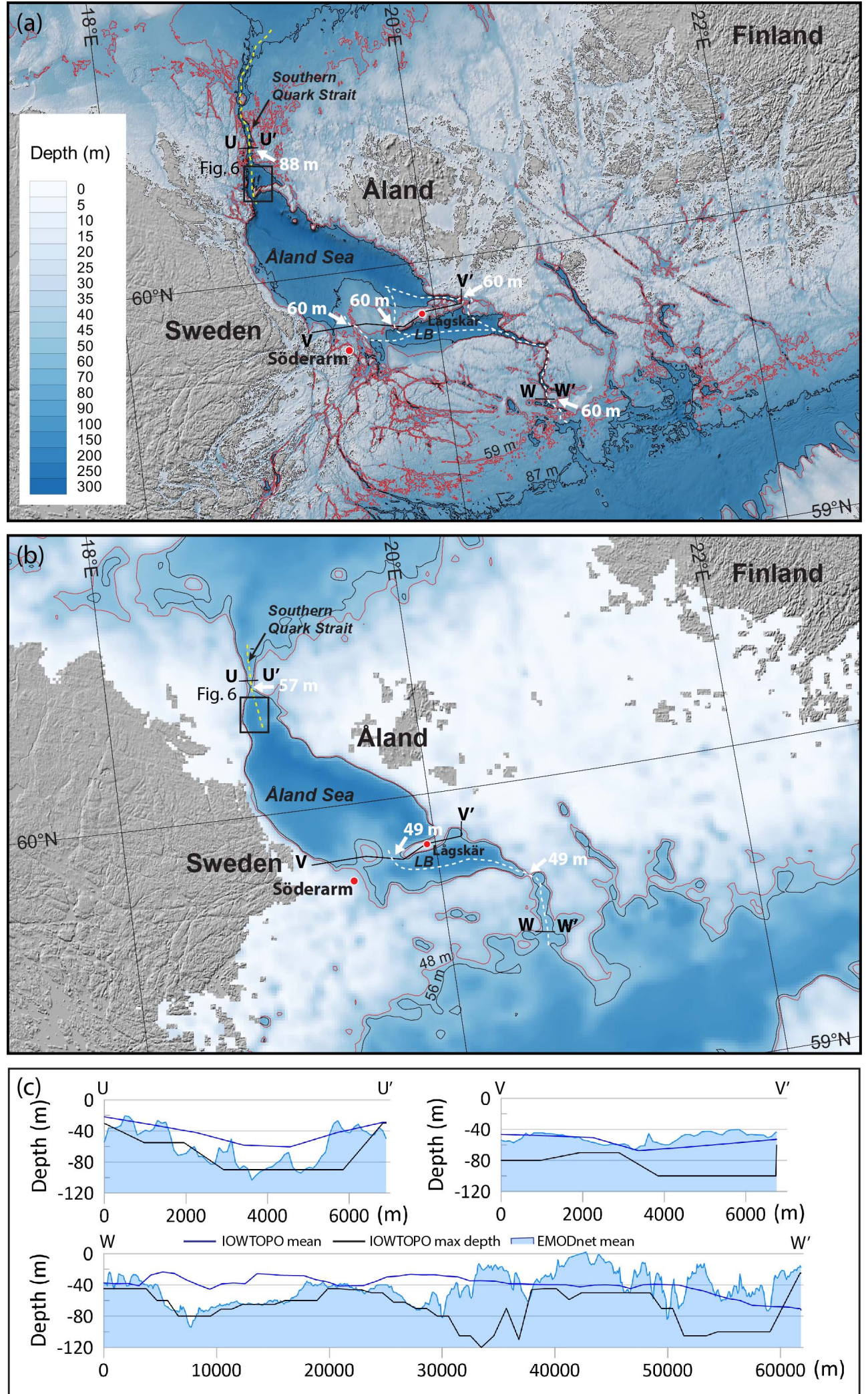

Figure 5. Åland Sea bathymetry, identified sill depths, and bathymetric profiles across the sills based on the EMODnet and IOWTOPO DBMs. (a) Bathymetry based on EMODnet. (b) Bathymetry based on IOWTOPO. White arrows show the locations of identified bathymetric sills with their depths written next to the arrows. The stippled white lines show the deepest pathways through the area. (c) Bathymetric profiles $\mathrm{U}-\mathrm{U}^{\prime}, \mathrm{V}-\mathrm{V}^{\prime}$, and $\mathrm{W}-\mathrm{W}^{\prime}$ across the identified sills. Their locations are shown in (a) and (b). Profiles are drawn using both EMODnet and IOWTOPO for comparison. The latter DBM also provides maximum depths of the grid cells. LB is Lågskär Basin. 

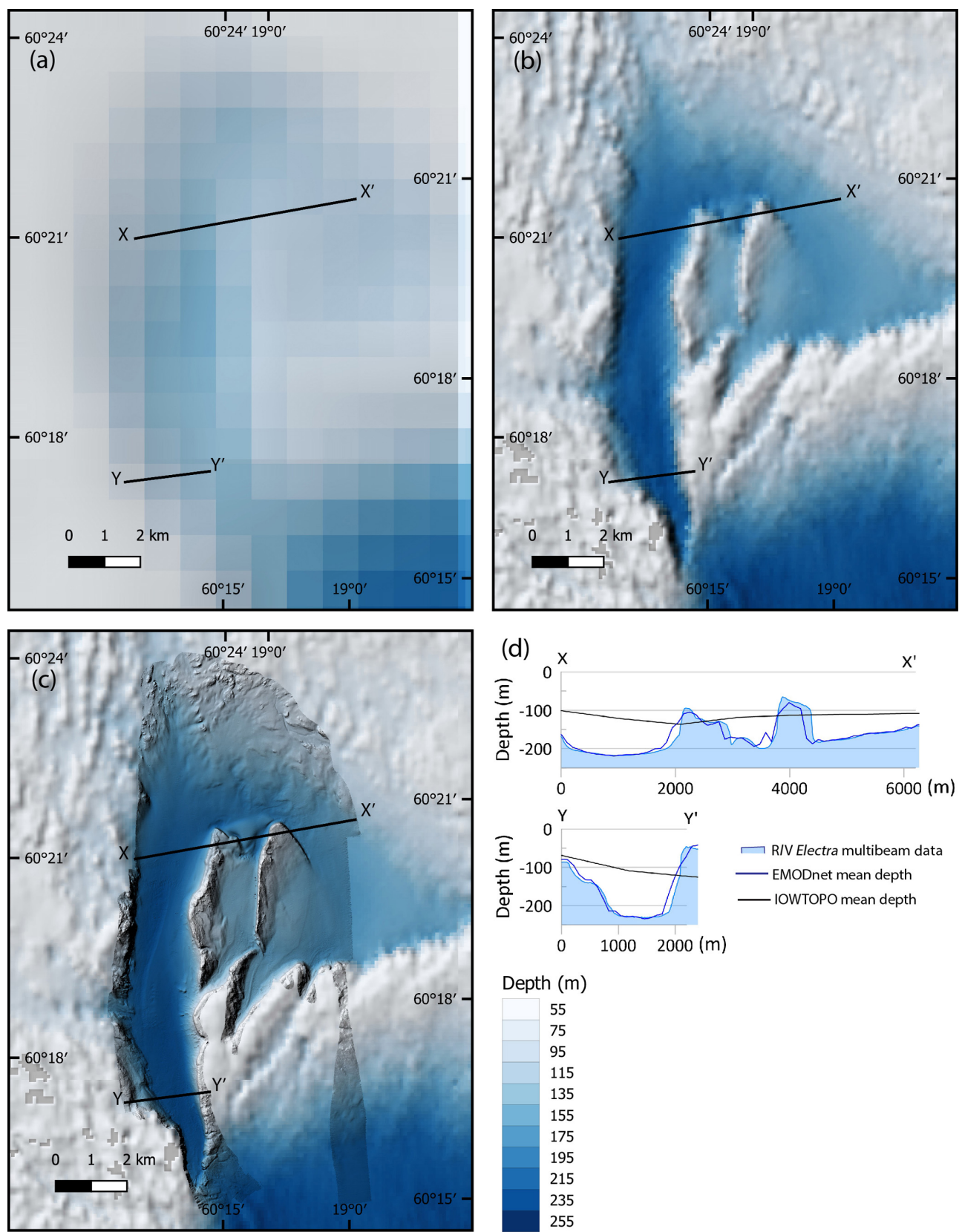

Figure 6. Bathymetry of the Southern Quark area based on IOWTOPO (a), EMODnet (b), and multibeam bathymetry acquired with R/V Electra (c). (d) Bathymetric profiles $\mathrm{X}-\mathrm{X}^{\prime}$ and $\mathrm{Y}-\mathrm{Y}^{\prime}$, drawn using the three different bathymetric datasets for comparison, show good correspondence between the R/V Electra multibeam and EMODnet mean depth, but extremely poor capture by IOWTOPO of ridges and channels relevant to water and sediment mobility.

bathymetric models. The decision to instead use the HELCOM definitions of the Baltic Sea and its sub-basins is justified as they are becoming standard in modern assessments of the marine environmental conditions (http://www.helcom. fi/baltic-sea-trends, last access: 2 July 2019). Nonetheless, the calculated area and volume for the entire Baltic Sea can still be compared directly to previous studies because only the sub-basins are defined differently in HELCOM.
Leppäranta and Myrberg (2009) reported an area and volume of the Baltic Sea (including the Kattegat) of $415265 \mathrm{~km}^{2}$ and $21720 \mathrm{~km}^{3}$, respectively, compared to our results of $417115 \mathrm{~km}^{2}$ and $21971 \mathrm{~km}^{3}$ based on EMODnet. The area and volume are thus $\sim 0.45 \%$ and $\sim 1.16 \%$ larger for EMODnet. These are rather close matches since the two base datasets are different, both with respect to age and type (contour maps versus DBM). If we instead compare calcu- 

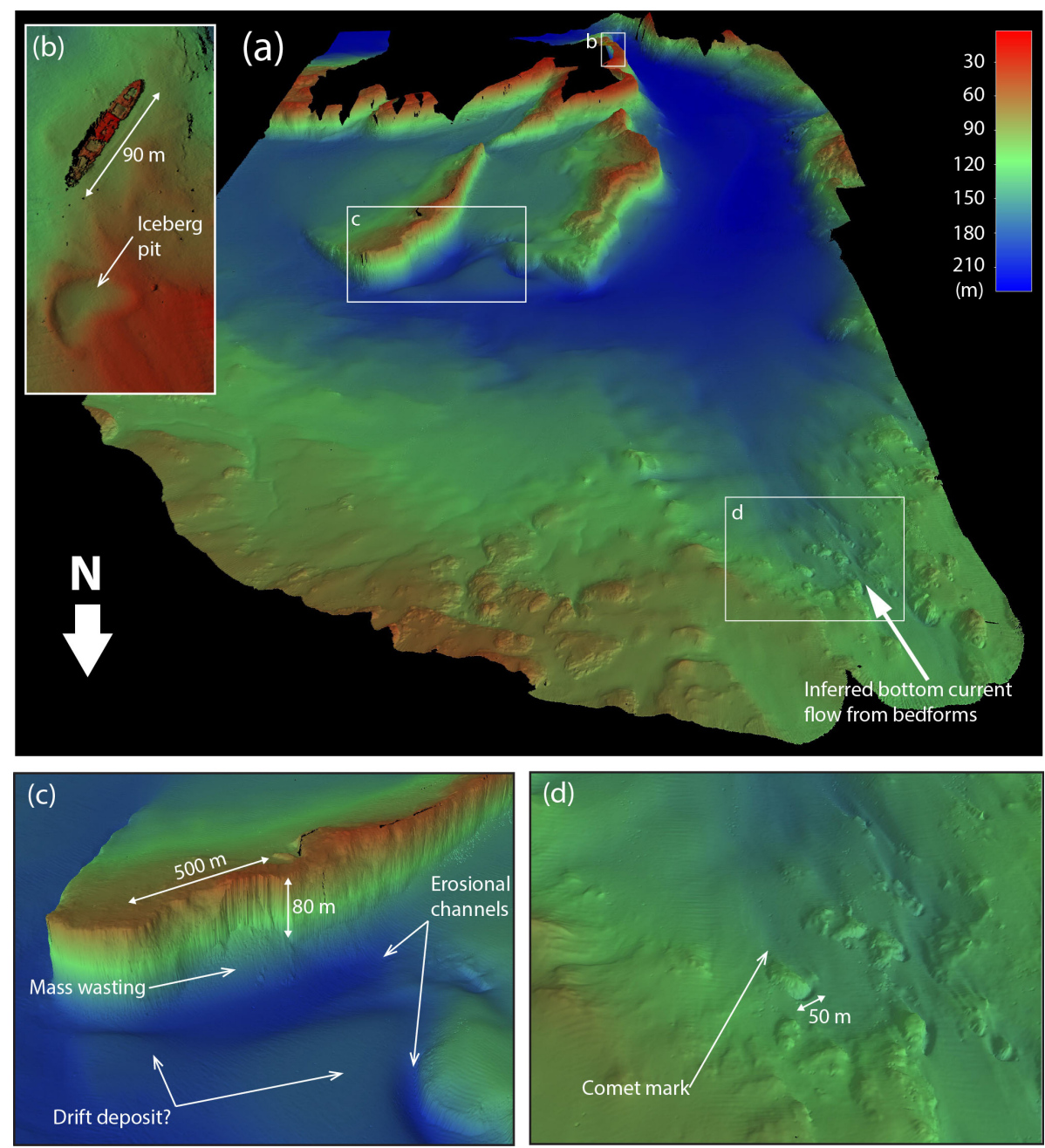

Figure 7. A 3-D view of the seafloor in the Southern Quark area based on the multibeam bathymetry acquired with R/V Electra. (a) Overview of the area looking south. (b) The $90 \mathrm{~m}$ long shipwreck of August Thyssen in $\sim 55 \mathrm{~m}$ water depth and an iceberg pit portrayed using a $50 \mathrm{~cm} \times 50 \mathrm{~cm}$ grid from the multibeam bathymetry. (c) Mass wasting, channels carved by bottom current scouring, and a potential drift deposit are identified in the bathymetric data. (d) Features formed by seafloor interaction with bottom currents.

lated area and volume between EMODnet and IOWTOPO, the differences are in fact much larger. IOWTOPO yields an area $\sim 2.5 \%$ larger and a volume $3.1 \%$ smaller than EMODnet. The explanation for these differences is found in the hypsometric curves (Fig. 2). The fact that IOWTOPO shows a larger area represented by depths shallower than $15 \mathrm{~m}$, particularly noticeable in the depth range of a couple of metres, will decrease the total volume. This shallow depth bias along coasts and islands is simply due to the coarser grid-cell resolution. There are thousands of islands and small slivers of land along complex coastlines that are not resolved and instead assigned a shallow depth during the interpolation process. A further consequence of this effect is that the ocean area increases.

We expect that future calculations of area and volume of the entire Baltic Sea based on a further improved DBM will yield only minor differences compared to the numbers pre- sented here. The Baltic Sea mean depth of $53 \mathrm{~m}$, calculated from the mean depth values in the grid cells of the EMODnet DBM, is within the 53-55 m that is commonly stated in encyclopaedias and published literature, although often without references to the used bathymetric dataset or applied definition of the Baltic Sea. However, there are other depth-related parameters that are more sensitive, e.g. the location of critical sills where a lack of bathymetric source data in small regions may have large effects (see discussion below).

\subsection{Seafloor ruggedness}

Ruggedness might be relevant to a number of geoscientific fields. For example, the ruggedness of a seafloor represents an aspect of "geodiversity", with implications for habitats (biodiversity) (Kaskela and Kotilainen, 2017); has implications for mixing and stratification (Umlauf et al., 2018; Jayne 

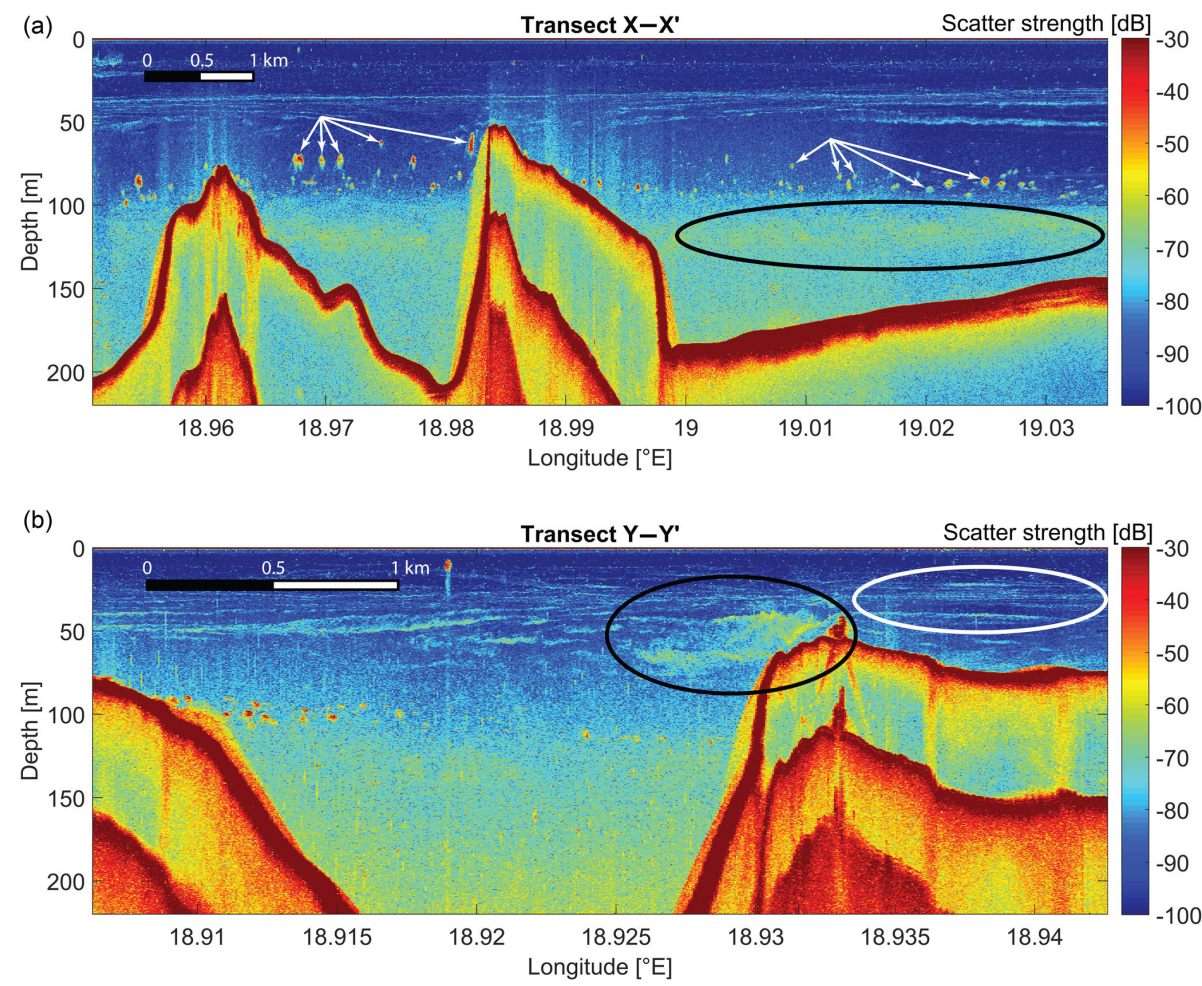

Figure 8. Scatter strength as a function of longitude and depth, from the Kongsberg EK80 split-beam echo sounder (wideband FM mode with centre frequency at $70 \mathrm{kHz}$ ). (a) The eastern part of the $\mathrm{X}-\mathrm{X}^{\prime}$ transect shown in Fig. $6 \mathrm{c}$, where examples of fish schools are marked with white arrows and a scattering layer (zooplankton and/or other suspended particles) below $100 \mathrm{~m}$ depth marked as black ellipse. (b) the Y-Y' transect in Fig. 6c, where the white ellipse shows an example of thermohaline stratification and black ellipse an example of turbulent mixing associated with the steep bathymetry. Note how the stratification (thin horizontal lines within the red ellipse) is interrupted by the turbulence, and is only seen intermittently westward of the steep slope.

et al., 2015); and influences flow over the seafloor, both now (bottom currents, sediment transport) and in the past (ice flow, glacial erosion and sediment transport, ice flow stability) (Kietzig et al., 2009). On an ocean-wide scale, for instance, the vertical mixing that occurs over rough sections of the Mid-Atlantic Ridge and other topographically complex areas in the world oceans influences the global overturning circulation (Wunsch and Ferrari, 2004; Ledwell et al., 2000).

The generalized bedrock geology map of the Baltic Sea by Uścinowicz (2014) reveals that TRI values and patterns in EMODnet coincide with variation in bedrock composition and positions of major faults and structures. The crisscross pattern of high TRI values along the Swedish east coast, beginning at northern Öland and stretching across the Åland Sea and along southern Finland (Fig. 4), coincides with the predominance of Proterozoic crystalline bedrock of the Baltic Shield. High TRI values along nearly straight lines follow major faults. The similar TRI pattern distinguished in Kattegat and from about $62^{\circ} 30^{\prime} \mathrm{N}$ in the Bothnian Sea, albeit with less pronounced criss-cross and straight lines of high TRI values, also occurs in areas generally composed of Proterozoic crystalline rocks. The sinuous pattern of high TRI values extending from the lower western corner of the
Baltic Proper and further into the southern Gulf of Finland (Fig. 4b) occurs where the generalized geological map by Uścinowicz (2014) shows a narrow belt of Cambrian sedimentary rocks, mainly sandstones. South of this belt, Ordovician, Silurian, and Devonian clastic and calcareous rocks provide the foundation for a smoother seafloor which is reflected in the TRI map (Fig. 4). Ancient crystalline surfaces have undergone (extremely) long periods of weathering and erosion, and fracture or joint patterns have been exploited to give a very visible surface morphological expression. This contrasts with horizontally, or slightly inclined, bedded sedimentary strata where surface expression is only really apparent when bedding planes crop out.

The Baltic Sea's bedrock geology is mainly inferred from seismic reflection and refraction surveys, dredging, and drilling (Grigelis, 2011). The apparent correlation between bedrock type and seafloor ruggedness suggests that a highresolution regional DBM could be a significant help to further refine bedrock boundaries and for discovering outcrops. However, the TRI-value pattern is not all inherited from the bedrock. We have already noted its dependence on the size of analysis neighbourhood and the effect of heterogeneous input datasets, where high-resolution survey data were 
downsampled. Furthermore, the macro-scale bedrock topography of the Baltic is overlain by Quaternary glacial, postglacial, and modern sediments and landforms, whose localscale morphology is superimposed on the underlying relief. The high TRI values that exhibit a patchy distribution in Fig. 4c reflect a drumlin field (Greenwood et al., 2017) superimposed on an otherwise rather low-relief surface. Here the boundaries of the multibeam dataset that reveals these drumlins are also clearly seen in the TRI pattern highlighting the need to consider the underlying source data when interpreting seafloor morphology using DBMs. This is further emphasized in our analyses of bathymetric sills.

\subsection{Bathymetric sills and seafloor processes}

Bathymetric sills in the Baltic Sea have been much discussed within the oceanographic community because of their influences on circulation patterns and direct control on water exchanges between basins and mixing (e.g. Laanearu and Lundberg, 2000; Lass and Mohrholz, 2003; Gustafsson, 2000; Omstedt et al., 2014). The sills affecting deep water exchange between the Bothnian Sea and the Northern Baltic Proper across Åland Sea (Ehlin and Ambjörn, 1977) will be discussed here because we have a high-resolution perspective provided by the R/V Electra survey of a section of the overflow area. In contrast to the well described and investigated sills and thresholds in the Danish sounds, the exchange of water between the central parts of the Baltic Sea and the Bothnian Sea is relatively unknown, especially the northbound flow of salt water and nutrients, which has been suggested to trigger major ecosystem changes in the Bothnian Sea both at present (Rolff and Elfwing, 2015) and in the past (Jilbert et al., 2015). Leppäranta and Myrberg (2009) identified three bathymetric sills influencing deep water exchange across Åland Sea: Southern Quark Strait (100 m), between Söderarm and Lågskär $(70 \mathrm{~m})$, and in a narrow channel in southern Åland Sea $(70 \mathrm{~m})$. These are three locations where we also locate the critical bathymetric sills in EMODnet, but find them all to be shallower: $88 \mathrm{~m}$ in the Southern Quark Strait and $60 \mathrm{~m}$ in the two other locations (Fig. 5a). In this context, it is appropriate to discuss the fact that depths provided by a DBM such as EMODnet represent grid cells, in our analysis having a size of $\sim 115 \mathrm{~m} \times 115 \mathrm{~m}$. EMODnet only contains mean depths for the grid cells in this particular region and no maximum or minimum depths, because the underlying source data from the Swedish Maritime Administration lacks this information here. When a maximum depth is provided for a grid cell, it could be used as the depth of a sill. However, this may be misleading because the maximum depth could be surrounded by shallower depths from the grid-cell area. If this is the case, the maximum depth would instead represent a local depression. The opposite is true if the minimum depth is used as it could be from a local obstacle. Neither will the mean depth be the most representative of a sill as large depth variations within the grid-cell area may exist. The problem of selecting the right depth increases with lower-resolution DBMs, which is clearly illustrated by our analysis of IOWTOPO2 (Fig. 5b and $\mathrm{c}$ ). The coarse resolution of the grid cells (originally $2 \operatorname{arcmin} \times 2 \operatorname{arcmin}$ ) makes it impossible to capture the critical details in the region between the Bothnian Sea and the Northern Baltic Proper where the sills are located (Fig. 5b). The problem is greater if the DBM is based on a sparse underlying source dataset requiring interpolation. Even if available ocean circulation models are not able to make use of the resolution provided by EMODnet, except when applied over small areas, the subsampling from higher to lower resolution can be made in such a way that critical sills are preserved.

The comparison between IOWTOPO2, EMODnet, and the multibeam data from R/V Electra in the Southern Quark area shows the strength of compiling a DBM by sub-sampling full-coverage high-resolution bathymetry instead of interpolating from heterogenic and sparse single-beam depth soundings (Fig. 6). The fact that EMODnet in the Southern Quark is based on complete multibeam surveys results in the main seafloor features being well portrayed, although the steepness of the walls and peaks of ridges are lost when downgrading the original resolution (Fig. 6d). From this it becomes clear that in critical areas, such as where bathymetric sills govern water circulation, full multibeam surveys are required for appropriate representation of the bathymetry, but that it may be adequate at a downgraded resolution.

For further insight into local-scale seafloor processes, fullresolution multibeam bathymetry provides valuable additional information (Fig. 7). While a full description of the seafloor features in the mapped area is beyond the scope of this paper, we point out and discuss some visible characteristic bedforms indicative of past glacial activity, bottom currents, and mass wasting. Glacial landforms are common in the surveyed area. For example, there is a semicircular $\sim 70 \mathrm{~m}$ wide and $\sim 4-5 \mathrm{~m}$ deep pit with pushed-up rims near the mapped wreck of August Thyssen (Fig. 7b). Similar features are widespread further north on crests of drumlins mapped by multibeam data (Greenwood et al., 2017; Jakobsson et al., 2016a). The pits are interpreted to form when icebergs lose their balance, due to melting or partial disintegration, and rotate to temporarily reach deeper with one corner making a dent in the seafloor or, alternatively, from icebergs with expressed pointy keels that ground in calm conditions so that they lift off the seafloor before elongated scours are formed. The image in Fig. 7b showing the iceberg pit and August Thyssen is created from a $50 \mathrm{~cm} \times 50 \mathrm{~cm}$ grid from a specific survey over the wreck using $400 \mathrm{kHz}$ mode instead of $300 \mathrm{kHz}$.

Characteristic seafloor bedforms, both erosional and depositional, have long been used to provide information on bottom current velocity and flow direction in studies of both modern and past oceanographic conditions (Hollister and Heezen, 1972; Kenyon and Belderson, 1973). With highresolution multibeam bathymetry acquired with surface ves- 
sels in relatively shallow waters such as in the Baltic Sea, we are able to make use of bedforms scaling from a few decimetres in size at the very best or, more commonly, from a few metres. Our multibeam bathymetry shows bedforms indicating substantial bottom currents in several areas of the Southern Quark. For example, along the western and northern foot of the steep wall of the ridge where mass wasting occurred, bottom currents appear to have scoured a $>20 \mathrm{~m}$ deep and $>200 \mathrm{~m}$ wide channel (Fig. 7c). A similar but smaller erosional channel is visible along the northern foot of the twinlike ridge located to the west. Next to the channels, the smooth texture and rounded seafloor morphology suggests sediment accumulations that may be drift deposits. These would be typical targets for further geophysical surveys and coring since they may contain a high-resolution sedimentary record of the bottom current flow over time across Åland Sea. Stow et al. (2009) constructed a bedform-velocity matrix that permits a first-order inference of bottom current velocity from mapped bedforms. This bedform index includes elongated erosive features around obstacles, often with elongated erosive tails. We identify these kind of bedforms, often called obstacles with comet marks, in the northern part of the surveyed area (Fig. 4d). The directions of their tails indicate a prevailing bottom current flow towards the southsoutheast. These bedforms, when large, may form under prevailing current flow regimes with velocities $>1 \mathrm{~m} \mathrm{~s}^{-1}$ (Stow et al., 2009). Key to this matrix is sediment composition implying that this information must supplement the shape and size of the bedforms inferred from geophysical seafloor mapping.

\subsection{Adding the midwater perspective}

Midwater echo sounders permit remote observations of thermohaline stratification (Stranne et al., 2017), turbulence (Farmer and Dungan Smith, 1980; Moum et al., 2003), and suspended particles (Young et al., 1982; Hay and Sheng, 1992), as well as individual fish, fish schools, and zooplankton (Chu et al., 1994). Advantages of the new type of wideband echo sounders that we used in this study compared to conventional narrow-band systems include increased signalto-noise ratio and increased range resolution (Stanton and Chu, 2008), as well as the ability to study the frequency response of individual targets to help identify the source of the acoustic backscatter (Weidner et al., 2019; Irish et al., 2010). While this kind of frequency response analysis has not been done on the data presented here, we can still visually identify some specific features in the acoustic mid-water profiles such as fish schools, zooplankton or suspended particles, thermohaline stratification (verified with co-located CTD data) and turbulence (Fig. 8). It is clear that the dramatic and steep bathymetric features in the Southern Quark influence, and in cases likely cause, processes in the water column (Fig. 8). This shows that through the combination of high-resolution bathymetry data and new wideband sonar technology, we can now collect acoustic data during surveys that will allow us to link (and possibly quantify) vertical mixing within the ocean interior associated with specific bathymetric features. In the Baltic Sea, mixing inferred from direct observations is typically 1 order of magnitude smaller than when quantifications of mixing are made from measured salinity variance (Reissmann et al., 2009). Although some of the "missing mixing" is likely related to upwelling and double diffusion (Umlauf et al., 2018), local mixing associated with rough and steep bathymetry might be underestimated in the Baltic Sea. This opens up for future studies where seafloor ruggedness can serve as a first-order indication of where midwater echo sounding surveys combined with oceanographic stations could provide a better and more complete view of mixing processes in the Baltic Sea.

\section{Conclusions}

Comparison between the IOWTOPO and EMODnet hypsometries shows that the area shallower than $\sim 15 \mathrm{~m}$ is overrepresented in IOWTOPO over much of the Baltic Sea, while depth differences between the two DBMs otherwise occur at various depth intervals in the different HELCOM sub-basins. This general shallow bias in IOWTOPO is mainly an effect from its coarser resolution. The shallow bias is also evident in the median and mean depths calculated for the two DBMs (IOWTOPO: median $=39 \mathrm{~m}$, mean $50 \mathrm{~m}$; EMODnet: median $=42 \mathrm{~m}$, mean $53 \mathrm{~m}$ ). The Baltic Sea area, defined as where grid-cell values are $\leq 0 \mathrm{~m}$ in the EMODnet DBM within the HELCOM spatial limits of the Baltic Sea, is $\sim 417 \times 10^{3} \mathrm{~km}^{2}\left(417115 \mathrm{~km}^{2}\right)$ and the volume is $\sim 21.9 \times 10^{3} \mathrm{~km}^{3}\left(21971 \mathrm{~km}^{3}\right)$. Using IOWTOPO, the calculated area is $\sim 2.5 \%$ larger while the volume is $\sim 3.1 \%$ smaller.

Analysis of kilometre-scale seafloor heterogeneity, through calculation of terrain ruggedness index (TRI) values using the EMODnet DBM, reveals patterns that generally coincide with variation in bedrock composition of the Baltic seafloor and positions of major faults and structures, with deviations where prominent glacial landforms, e.g. drumlin fields, superimpose the underlying relief. TRI patterns originating from heterogenic bathymetric source data are also evident from the analysis.

Three areas having bathymetric sills likely influencing deep-water exchange across the Åland Sea are identified in the EMODnet DBM: (1) in the Southern Quark Strait (sill depth $\sim 88 \mathrm{~m}$, at about $60^{\circ} 26.6^{\prime} \mathrm{N}, 18^{\circ} 56.8^{\prime} \mathrm{E}$ ), (2) at three locations along a transect from north of Söderarm to east of Lågskär (sill depth at all three $\sim 60 \mathrm{~m}$ ), and (3) in a narrow channel in the Northern Baltic Proper (sill depth $\sim 60 \mathrm{~m}$ at about $59^{\circ} 30.1^{\prime} \mathrm{N}, 20^{\circ} 37.3^{\prime} \mathrm{E}$ ). The locations of these bathymetric sills have previously been identified, although their depths were assumed to be significantly deeper. The IOWTOPO DBM suggests both different locations and depths of 
bathymetric sills that would influence water exchange across the Åland Sea, which is an effect of its lower resolution and less bathymetric source data available during the compilation.

High-resolution multibeam bathymetry from the Southern Quark shows that the EMODnet DBM, here based on downgraded multibeam bathymetry, captures the general topography rather well but fails to reveal mass wasting, seafloor features indicative of bottom currents, and glacial landforms evident in the high-resolution bathymetry. This shows the enormous value in full-resolution bathymetric information in marine research and the need for a complete high-resolution mapping of the Baltic Sea seafloor.

Data availability. The EMODnet DBM is available for download from the portal: http://portal.emodnet-bathymetry.eu (last access: 2 July 2019). The IOWTOPO is available from the Leibniz Institute for Baltic Sea Research Warnemünde at https: //www.io-warnemuende.de/topography-of-the-baltic-sea.html (last access: 2 July 2019). The multibeam bathymetry and midwater imagery acquired by R/V Electra presented in this work were granted public release by the Swedish Maritime Administration (release 1703187). These data are available for download from the Bolin Centre Database https://bolin.su.se/data/jakobsson-2019-2 (Stranne, 2019). The TRI dataset generated in this study is provided through the direct link: https://bolin.su.se/data/jakobsson-2019 (Jakobsson, 2019).

Author contributions. MJ prepared the article with input from all co-authors. MJ analysed the DBMs and processed the R/V Electra multibeam bathymetry and CS processed the EK80 data. MJ, MO, and LW carried out the geophysical mapping with R/V Electra.

Competing interests. The authors declare that they have no conflict of interest.

Acknowledgements. We thank the crew and captain of R/V Electra and the Baltic Sea Centre for their support. The survey with R/V Electra forms a part of a project financed by the Swedish Radiation Safety Authority. Martin Jakobsson worked on this paper during sabbatical leave supported by Stockholm University and thank NIWA (National Institute of Water and Atmospheric Research) in Wellington, New Zealand, for providing a work space during the sabbatical. Geoffroy Lamarche at NIWA is specifically thanked for fruitful discussions. Thierry Smith and two anonymous reviewers are thanked for insightful and constructive comments and suggestions. We also thank Hans Öiås from the Swedish Maritime Administration for providing comments on the article.

Financial support. This research has been supported by the Swedish Radiation Safety Authority (grant no. SSM2016-644).
The article processing charges for this open-access publication were covered by Stockholm University.

Review statement. This paper was edited by Mario Hoppema and reviewed by Thierry Schmitt and two anonymous referees.

\section{References}

Bendtsen, J., Gustafsson, K. E., Söderkvist, J., and Hansen, J. L. S.: Ventilation of bottom water in the North SeaBaltic Sea transition zone, J. Mar. Syst., 75, 138-149, https://doi.org/10.1016/j.jmarsys.2008.08.006, 2009.

Chu, D., Eastwood, R. L., Stanton, T. K., Martin, L., Benfield, M. C., Wiebe, P. H., and Scanlon, L.: On acoustic estimates of zooplankton biomass, ICES J. Mar. Sci., 51, 505-512, https://doi.org/10.1006/jmsc.1994.1051, 1994.

Conrad, O., Bechtel, B., Bock, M., Dietrich, H., Fischer, E., Gerlitz, L., Wehberg, J., Wichmann, V., and Böhner, J.: System for Automated Geoscientific Analyses (SAGA) v. 2.1.4, Geosci. Model Dev., 8, 1991-2007, https://doi.org/10.5194/gmd-8-1991-2015, 2015.

Dargahi, B., Kolluru, V., and Cvetkovic, V.: Multi-Layered Stratification in the Baltic Sea: Insight from a Modeling Study with Reference to Environmental Conditions, J. Mar. Sci. Eng., 5, 126, https://doi.org/10.3390/jmse5010002, 2017.

Ehlin, U. and Ambjörn, C.: Water Transport through the Åland Sea, in: 3rd Soviet-Swedish Symposium on the Pollution of the Baltic, in: Ambio Special Reports, Royal Swedish Academy of Sciences, Springer, Rosenön, Stockholm, Sweden, 117-125, 1977.

EMODnet Bathymetry Consortium: EMODnet Digital Bathymetry (DTM), European Marine Observation and Data Network, https://doi.org/10.12770/18ff0d48-b203-4a6594a9-5fd8b0ec35f6, 2018.

Farmer, D. M. and Dungan Smith, J.: Tidal interaction of stratified flow with a sill in Knight Inlet, Deep-Sea Res. Pt. A, 27, 239254, https://doi.org/10.1016/0198-0149(80)90015-1, 1980.

Fonselius, S.: Västerhavets och Östersjöns oceanografi, Sveriges meteorologiska och hydrologiska Institut (SMHI), Norrköping, Sweden, 1995.

Gogina, M. and Zettler, M. L.: Diversity and distribution of benthic macrofauna in the Baltic Sea: Data inventory and its use for species distribution modelling and prediction, J. Sea Res., 64, 313-321, https://doi.org/10.1016/j.seares.2010.04.005, 2010.

Greenwood, S. L., Clason, C. C., Nyberg, J., Jakobsson, M., and Holmlund, P.: The Bothnian Sea ice stream: early Holocene retreat dynamics of the south-central Fennoscandian Ice Sheet, Boreas, 46, 346-362, https://doi.org/10.1111/bor.12217, 2017.

Grigelis, A.: Research of the Bedrock Geology of the Central Baltic Sea, Baltica, 24, 1-12, 2011.

Gustafsson, B. G.: Time-Dependent Modeling of the Baltic Entrance Area. 1. Quantification of Circulation and Residence Times in the Kattegat and the Straits of the Baltic Sill, Estuaries, 23, 231-252, https://doi.org/10.2307/1352830, 2000.

Hay, A. E. and Sheng, J.: Vertical profiles of suspended sand concentration and size from multifrequency acoustic backscatter, J. Geophys. Res.-Oceans, 97, 15661-15677, https://doi.org/10.1029/92JC01240, 1992. 
HELCOM: State of the Baltic Sea - Second HELCOM holistic assessment 2011-2016, Baltic Marine Environment Protection Commission - HELCOM, Helsinki, Finland, 2018.

Hell, B. and Öiås, H.: A New Bathymetry Model for the Baltic Sea, Int. Hydrogr. Rev., 12, 21-31, 2014.

Hell, B., Broman, B., Jakobsson, L., Jakobsson, M., Magnusson, A., and Wiberg, P.: The Use of Bathymetric Data in Society and Science: A Review from the Baltic Sea, Ambio, 41, 138-150, https://doi.org/10.1007/s13280-011-0192-y, 2012.

Hollister, C. D. and Heezen, B. C.: Geologic effects of ocean bottom currents, in: Studies in physical oceanography, edited by: Gordon, A. L., Gordon \& Breach, New York, 37-66, 1972.

INSPIRE Thematic Working Group Coordinate Reference Systems and Geographical Grid Systems: D2.8.I.1 INSPIRE Specification on Coordinate Reference Systems - Guidelines, European Commission, Dublin, Ireland, 22 pp., https://inspire.ec.europa.eu/id/ document/tg/gg (last access: 2 July 2019), 2010.

International Hydrographic Organization: Limits of Oceans and Seas, International Hydrographic Organization, Monaco, 1-38, 1953.

Irish, J. D., Stanton, T. K., Chu, D., and Jech, J. M.: New broadband methods for resonance classification and high-resolution imagery of fish with swimbladders using a modified commercial broadband echosounder, ICES J. Mar. Sci., 67, 365-378, https://doi.org/10.1093/icesjms/fsp262, 2010.

Jakobsson, M.: Calculated seafloor ruggedness index (TRI) of the Baltic Sea, The Bolin Centre Database, Stockholm University, available at: https://bolin.su.se/data/jakobsson-2019, 2019.

Jakobsson, M., Calder, B., and Mayer, L.: On the effect of random errors in gridded bathymetric compilations, J. Geophys. Res., 107, 1-11, 2002.

Jakobsson, M., Macnab, R., Mayer, L., Anderson, R., Edwards, M., Hatzky, J., Schenke, H. W., and Johnson, P.: An improved bathymetric portrayal of the Arctic Ocean: Implications for ocean modeling and geological, geophysical and oceanographic analyses, Geophys. Res. Lett., 35, L07602, https://doi.org/10.1029/2008g1033520, 2008.

Jakobsson, M., Greenwood, S. L., Hell, B., and Öiås, H.: Drumlins in the Gulf of Bothnia, Geological Society, London, Memoirs, 46, 197-198, https://doi.org/10.1144/m46.43, 2016a.

Jakobsson, M., Gyllencreutz, R., Mayer, L. A., Dowdeswell, J. A., Canals, M., Todd, B. J., Dowdeswell, E. K., Hogan, K. A., and Larter, R. D.: Mapping submarine glacial landforms using acoustic methods, Memoirs, Geological Society, London, 46, 17-40, https://doi.org/10.1144/m46.182, $2016 \mathrm{~b}$.

Jayne, S. R., Laurent, L. C. S., and Gille, S. T.: Connections Between Ocean Bottom Topography and Earth's Climate, Oceanography, 17, 65-74, https://doi.org/10.5670/oceanog.2004.68, 2015.

Jilbert, T., Conley, D. J., Gustafsson, B. G., Funkey, C. P., and Slomp, C. P.: Glacio-isostatic control on hypoxia in a high-latitude shelf basin, Geology, 43, 427-430, https://doi.org/10.1130/g36454.1, 2015.

Kaskela, A. M. and Kotilainen, A. T.: Seabed geodiversity in a glaciated shelf area, the Baltic Sea, Geomorphology, 295, 419435, https://doi.org/10.1016/j.geomorph.2017.07.014, 2017.

Kenyon, N. H. and Belderson, R. H.: Bed forms of the Mediterranean undercurrent observed with side-scan sonar, Sediment.
Geol., 9, 77-99, https://doi.org/10.1016/0037-0738(73)90027-4, 1973.

Kietzig, A.-M., Hatzikiriakos, S. G., and Englezos, P.: Ice friction: The effects of surface roughness, structure, and hydrophobicity, J. Appl. Phys., 106, 024303, https://doi.org/10.1063/1.3173346, 2009.

Laanearu, J. and Lundberg, P.: Topographic control of rotating deep water flow through the combination of a sill and a horizontal constriction, J. Geophys. Res.-Oceans, 105, 28663-28669, https://doi.org/10.1029/2000JC900136, 2000.

Lappe, C. and Umlauf, L.: Efficient boundary mixing due to near-inertial waves in a nontidal basin: Observations from the Baltic Sea, J. Geophys. Res.-Oceans, 121, 8287-8304, https://doi.org/10.1002/2016JC011985, 2016.

Lass, H. U. and Mohrholz, V.: On dynamics and mixing of inflowing saltwater in the Arkona Sea, J. Geophys. Res.-Oceans, 108, 3042, https://doi.org/10.1029/2002JC001465, 2003.

Ledwell, J. R., Montgomery, E. T., Polzin, K. L., St. Laurent, L. C., Schmitt, R. W., and Toole, J. M.: Evidence for enhanced mixing over rough topography in the abyssal ocean, Nature, 403, 179182, https://doi.org/10.1038/35003164, 2000.

Leppäranta, M. and Myrberg, K.: Physical Oceanography of the Baltic Sea, Springer-Praxis, Heidelberg, Germany, 2009.

Lessin, G., Raudsepp, U., and Stips, A.: Modelling the Influence of Major Baltic Inflows on Near-Bottom Conditions at the Entrance of the Gulf of Finland, PLOS ONE, 9, e112881, https://doi.org/10.1371/journal.pone.0112881, 2014.

Li, Z.: Digital Terrain Modeling: Principles and Methodology, 1st Edn., CRC Press, Boca Raton, 323 pp., 2004.

Mayer, L., Jakobsson, M., Allen, G., Dorschel, B., Falconer, R., Ferrini, V., Lamarche, G., Snaith, H., and Weatherall, P.: The Nippon Foundation - GEBCO Seabed 2030 Project: The Quest to See the World's Oceans Completely Mapped by 2030, Geosciences, 8, 63, https://doi.org/10.3390/geosciences8020063, 2018.

Meier, H. E. M., Döscher, R., and Faxén, T.: A multiprocessor coupled ice-ocean model for the Baltic Sea: Application to salt inflow, J. Geophys. Res.-Oceans, 108, 3273, https://doi.org/10.1029/2000JC000521, 2003.

Moum, J. N., Farmer, D. M., Smyth, W. D., Armi, L., and Vagle, S.: Structure and Generation of Turbulence at Interfaces Strained by Internal Solitary Waves Propagating Shoreward over the Continental Shelf, J. Phys. Oceanogr., 33, 2093-2112, https://doi.org/10.1175/15200485(2003)033<2093:SAGOTA>2.0.CO;2, 2003.

National Geophysical Data Center: ETOPO-5 Bathymetry/Topography (Data Data Announcement 88MGG-02, National Oceanic and Atmospheric Administration, US Department of Commerce), National Geophysical Data Center, Boulder, CO, 1988.

Nohr, C. and Gustafsson, B. G.: Computation of energy for diapycnal mixing in the Baltic Sea due to internal wave drag acting on wind-driven barotropic currents, Oceanologia, 41, 461-494, https://doi.org/10.5697/oc.51-4.461 2009.

Omstedt, A., Elken, J., Lehmann, A., Leppäranta, M., Meier, H. E. M., Myrberg, K., and Rutgersson, A.: Progress in physical oceanography of the Baltic Sea during the 2003-2014 period, Prog. Oceanogr., 128, 139-171, https://doi.org/10.1016/j.pocean.2014.08.010, 2014. 
Pike, R. J., Evans, I., and Hengl, T.: Geomorphometry: A Brief Guide, in: Geomorphometry-Concepts, Software, Applications, edited by: Hengl, T. and Reuter, H. I., Series Developments in Soil Science, Elsevier, Amsterdam, 3-33, 2008.

QGIS Development Team: QGIS Geographic Information System, Open Source Geospatial Foundation Project, Version 3.4.1, Madeira, available at: https://qgis.org (last access: 2 July 2019), 2018.

Reissmann, J. H., Burchard, H., Feistel, R., Hagen, E., Lass, H. U., Mohrholz, V., Nausch, G., Umlauf, L., and Wieczorek, G.: Vertical mixing in the Baltic Sea and consequences for eutrophication - A review, Prog. Oceanogr., 82, 47-80, https://doi.org/10.1016/j.pocean.2007.10.004, 2009.

Riley, S. J., De Gloria, S. D., and Elliot, R.: A Terrain Ruggedness that Quantifies Topographic Heterogeneity, Intermount. J. Sci., 5, 23-27, 1999.

Rolff, C. and Elfwing, T.: Increasing nitrogen limitation in the Bothnian Sea, potentially caused by inflow of phosphaterich water from the Baltic Proper, Ambio, 44, 601-611, https://doi.org/10.1007/s13280-015-0675-3, 2015.

Seifert, T. and Kayser, B.: A high resolution sperical grid topography of the Baltic Sea, Leibniz Institute for Baltic Sea Research, Warnermünde, 72-88, 1995.

Seifert, T., Tauber, F., and Kayser, B.: A high resolution spherical grid topography of the Baltic Sea - 2nd edition, Baltic Sea Science Congress, 25-29 November 2001, Stockholm, 2001.

Smith, W. H. F. and Sandwell, D. T.: Global seafloor topography from satellite altimetry and ship depth soundings, Science, 277, 1957-1962, https://doi.org/10.1126/science.277.5334.1956, 1997.

Stanton, T. K. and Chu, D.: Calibration of broadband active acoustic systems using a single standard spherical target, J. Acoust. Soc. Am., 124, 128-136, https://doi.org/10.1121/1.2917387, 2008.

Stigebrandt, A.: Physical oceanography of the Baltic Sea, in: A Systems Analysis of the Baltic Sea, edited by: Wulff, F. V., Rahm, L., and Larsson, P., Springer, Berlin, Heidelberg, 353-372, 2001.

Stow, D. A. V., Hernández-Molina, F. J., Llave, E., SayagoGil, M., Río, V. D. D., and Branson, A.: Bedformvelocity matrix: The estimation of bottom current velocity from bedform observations, Geology, 37, 327-330, https://doi.org/10.1130/G25259A.1, 2009.
Stranne, C.: Acoustic midwater data from the Southern Quark, Baltic Sea, 2017, The Bolin Centre Database, Stockholm University, available at: https://bolin.su.se/data/jakobsson-2019-2, 2019.

Stranne, C., Mayer, L., Weber, T. C., Ruddick, B. R., Jakobsson, M., Jerram, K., Weidner, E., Nilsson, J., and Gårdfeldt, K.: Acoustic Mapping of Thermohaline Staircases in the Arctic Ocean, Scient. Rep., 7, 15192, https://doi.org/10.1038/s41598-017-154863, 2017.

Tuomi, L., Miettunen, E., Alenius, P., and Myrberg, K.: Evaluating hydrography, circulation and transport in a coastal archipelago using a high-resolution 3D hydrodynamic model, J. Mar. Syst., 180, 24-36, https://doi.org/10.1016/j.jmarsys.2017.12.006, 2018.

Umlauf, L., Holtermann, P. L., Gillner, C. A., Prien, R. D., Merckelbach, L., and Carpenter, J. R.: Diffusive Convection under Rapidly Varying Conditions, J. Phys. Oceanogr., 48, 1731-1747, https://doi.org/10.1175/jpo-d-18-0018.1, 2018.

Uścinowicz, S.: Chapter 7 The Baltic Sea continental shelf, Memoirs, Geological Society, London, 41, 69-89, https://doi.org/10.1144/M41.7, 2014.

Weidner, E., Weber, T. C., Mayer, L., Jakobsson, M., Chernykh, D., and Semiletov, I.: A wideband acoustic method for direct assessment of bubble-mediated methane flux, Cont. Shelf Res., 173, 104-115, https://doi.org/10.1016/j.csr.2018.12.005, 2019.

Wilson, M. F. J., O'Connell, B., Brown, C., Guinan, J. C., and Grehan, A. J.: Multiscale Terrain Analysis of Multibeam Bathymetry Data for Habitat Mapping on the Continental Slope, Mar. Geodesy, 30, 3-35, https://doi.org/10.1080/01490410701295962, 2007.

Wunsch, C. and Ferrari, R.: Vertical mixing, energy, and the general circulation of the oceans, Annu. Rev. Fluid Mech., 36, 281-314, https://doi.org/10.1146/annurev.fluid.36.050802.122121, 2004.

Young, R. A., Merrill, J. T., Clarke, T. L., and Proni, J. R.: Acoustic profiling of suspended sediments in the marine bottom boundary layer, Geophys. Res. Lett., 9, 175-178, https://doi.org/10.1029/GL009i003p00175, 1982. 